University of Nebraska - Lincoln

DigitalCommons@University of Nebraska - Lincoln

Papers in the Earth and Atmospheric Sciences

Earth and Atmospheric Sciences, Department

2020

\title{
Surficial fractures in the Navajo sandstone, south-western USA: the roles of thermal cycles, rainstorms, granular disintegration, and iterative cracking
}

\author{
David Loope \\ University of Nebraska - Lincoln, dloope1@unl.edu \\ Garrison R. Loope \\ University of Arizona, gloope@email.arizona.edu \\ Caroline M. Burberry \\ University of Nebraska - Lincoln, cburberry2@unl.edu \\ Clinton Rowe \\ University of Nebraska-Lincoln, crowe1@unl.edu \\ Gerald C. Bryant \\ Dixie State University
}

Follow this and additional works at: https://digitalcommons.unl.edu/geosciencefacpub

Part of the Earth Sciences Commons

Loope, David; Loope, Garrison R.; Burberry, Caroline M.; Rowe, Clinton; and Bryant, Gerald C., "Surficial fractures in the Navajo sandstone, south-western USA: the roles of thermal cycles, rainstorms, granular disintegration, and iterative cracking" (2020). Papers in the Earth and Atmospheric Sciences. 621. https://digitalcommons.unl.edu/geosciencefacpub/621

This Article is brought to you for free and open access by the Earth and Atmospheric Sciences, Department of at DigitalCommons@University of Nebraska - Lincoln. It has been accepted for inclusion in Papers in the Earth and Atmospheric Sciences by an authorized administrator of DigitalCommons@University of Nebraska - Lincoln. 


\title{
Surficial fractures in the Navajo sandstone, south-western USA: the roles of thermal cycles, rainstorms, granular disintegration, and iterative cracking
}

\author{
David B. Loope, ${ }^{1}$ Garrison R. Loope, ${ }^{2}$ Caroline M. Burberry, ${ }^{1}$ \\ Clinton M. Rowe, ${ }^{1} \&$ Gerald C. Bryant ${ }^{3}$
}

1 Earth \& Atmospheric Sciences, University of Nebraska-Lincoln, Lincoln, NE, USA

2 Geosciences, University of Arizona, Tucson, AZ, USA

3 Physical Sciences, Dixie State University, St George, UT, USA

Corresponding author: David B. Loope, 126 Bessey Hall, Earth \& Atmospheric Sciences, University of Nebraska-Lincoln, Lincoln, NE 68588-0340, USA. E-mail: dloope1@unl.edu

\begin{abstract}
Deep ( $>5 \mathrm{~m}$ ) sheeting fractures in the Navajo sandstone are evident at numerous sites in southern Utah and derive from tectonic stresses. Strong diurnal thermal cycles are, however, the likely triggers for shallow $(<0.3 \mathrm{~m})$ sheeting fractures. Data from subsurface thermal sensors reveal that large temperature differences between sensors at 2 and $15 \mathrm{~cm}$ depth on clear summer afternoons are as great as those that trigger sheeting fractures in exposed California granite. Extensive polygonal patterns in the Navajo sandstone are composed of surface-perpendicular fractures and were produced by contractile stresses. Numerous studies have shown that porewater diminishes the tensile strength of sandstone. Based on our thermal records, we propose that cooling during monsoonal rainstorms triggers polygonal fracturing of temporarily weakened rock. On steep outcrops, polygonal patterns are rectilinear and orthogonal, with T-vertices. Lower-angle slopes host hexagonal patterns (defined by the dominance of $Y$-vertices). Intermediate patterns with rectangles and hexagons of similar scale are common. We posit that outcropping fractures are
\end{abstract}

Published in Earth Surface Processes and Landforms 45 (2020), pp 2063-2077.

DOI: 10.1002/esp.4866

Copyright (C) 2020 John Wiley \& Sons, Ltd. Used by permission.

Submitted 19 February 2019; revised 24 March 2020; accepted 26 March 2020. 
advancing downward by iterative steps, and that hexagons on sandstone surfaces (like prismatic columns of basalt) have evolved from ancestral orthogonal polygons of similar scale. In lava flows, fractures elongate intermittently as they follow a steep thermal gradient (the source of stress) as it rapidly moves through the rock mass. In our model, a steep, surficial thermal gradient descends through unfractured sandstone, but at the slow pace of granular disintegration. Through time, as the friable rock on stable slopes erodes, iterative cracking advances into new space. Hexagonal patterns form as new fractures, imperfectly guided by the older ones, propagate in new directions, and vertices drift into a configuration that minimizes the ratio of fracture length to polygon area.

Keywords: polygonal fracture, sheeting joint, Navajo sandstone, hexagonal pattern, diurnal thermal cycle, Colorado Plateau, fracture network

\section{Introduction}

The diverse and aesthetically pleasing landforms developed on eolian sandstones of the Colorado Plateau, USA have long been heralded by writers, photographers, hikers, and geologists (Abbey and Hyde, 1971; Crampton, 1973; Hamilton et al., 1984; Young et al., 2009). The sheeting fractures that form on the Plateau's naked rock surfaces (Bradley, 1963; Howard and Kochel, 1988; Loope and Burberry, 2018) drive the evolution of the landscape by accelerating mass wasting of the sandstone, but their origins and those of associated polygonal fracture patterns have received little attention.

Studies of exposed granite using thermal and acoustic monitoring (Eppes et al., 2016; Collins et al., 2018) have demonstrated that diurnal insolation cycles and wetting events can drive subcritical fracturing that weakens outcropping boulders and bedrock, leading to the initiation and propagation of macroscopic fractures, and culminating in rock failure. On granite domes, the hottest days of California summers trigger explosive events in which massive rock slabs can become airborne (Collins et al., 2018). Although horizontal, compressive tectonic stress can be the sole contributor to formation of sheeting joints (Holzhausen, 1989; Martel, 2011, 2017), Collins et al. (2018) showed that, in granite, augmentation of regional stress by thermal stress triggers near-surface sheeting fractures. Their work explains why these fractures are more closely spaced near land surfaces.

Chan et al. (2008) showed that polygonal patterns similar to those exposed on the surface of Mars are widespread on outcrops of Navajo 


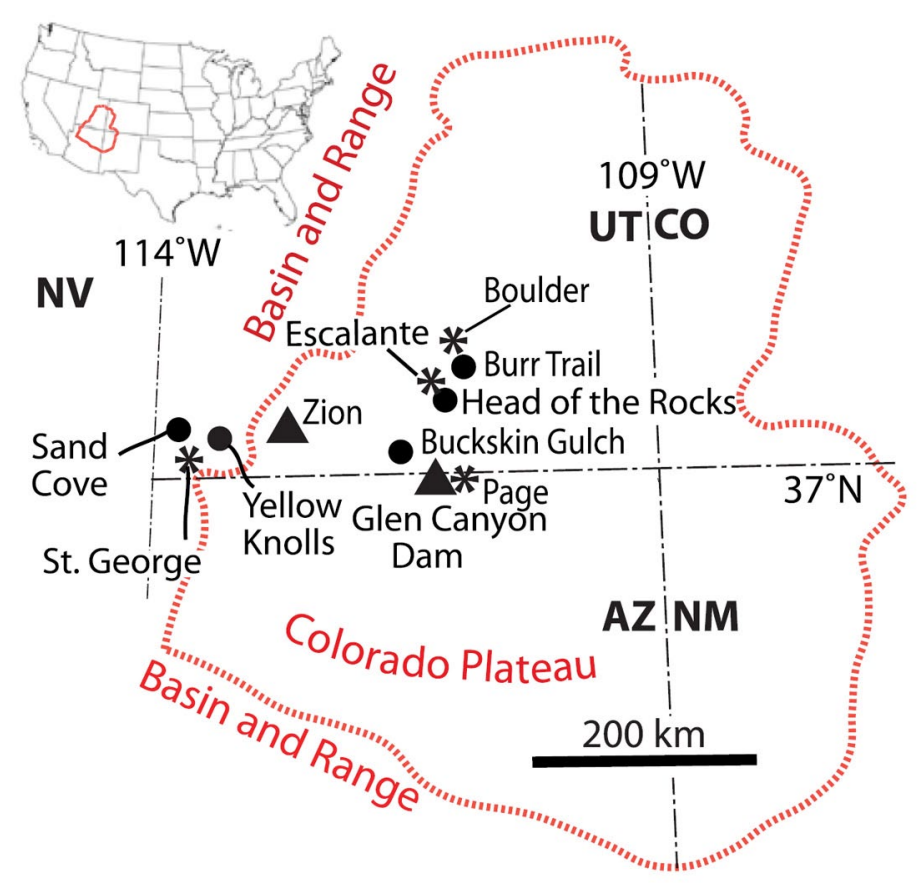

Figure 1. Location map for four weather stations (asterisks), five study sites (solid circles), and two places mentioned in the text (triangles). A high percentage of all Navajo sandstone exposures occur in the Colorado Plateau province of Utah and Arizona.

sandstone on the Colorado Plateau (Figure 1) and hypothesized that they may have originated via thermal stresses. Polygons are especially well developed in sheet-jointed exposures, where the two fracture types are interlaced (Loope and Burberry, 2018). Hexagonal fracture patterns (polygonal patterns that are dominated by " $\mathrm{Y}$ " vertices rather than the " $T$ " vertices of orthogonal patterns) have been described from sandstones around the world (Johnston, 1927; Netoff, 1971; Branagan, 1983; Williams and Robinson, 1989; Robinson and Williams, 1992; Thomas et al., 2005; Young et al., 2009). They are common in massive (unstratified) outcrops of the Navajo sandstone (Chan et al., 2008; Loope and Burberry, 2018). However, the most uniform, hexagon-dominated fracture systems that we describe here formed instead on multiple surfaces parallel to bedding (Figure 2).

A fracture pattern dominated by hexagons relieves the maximum amount of elastic energy for a given total length of fractures (Weaire and Hutzer, 1999; Jagla and Rojo, 2002). Many studies of desiccating 

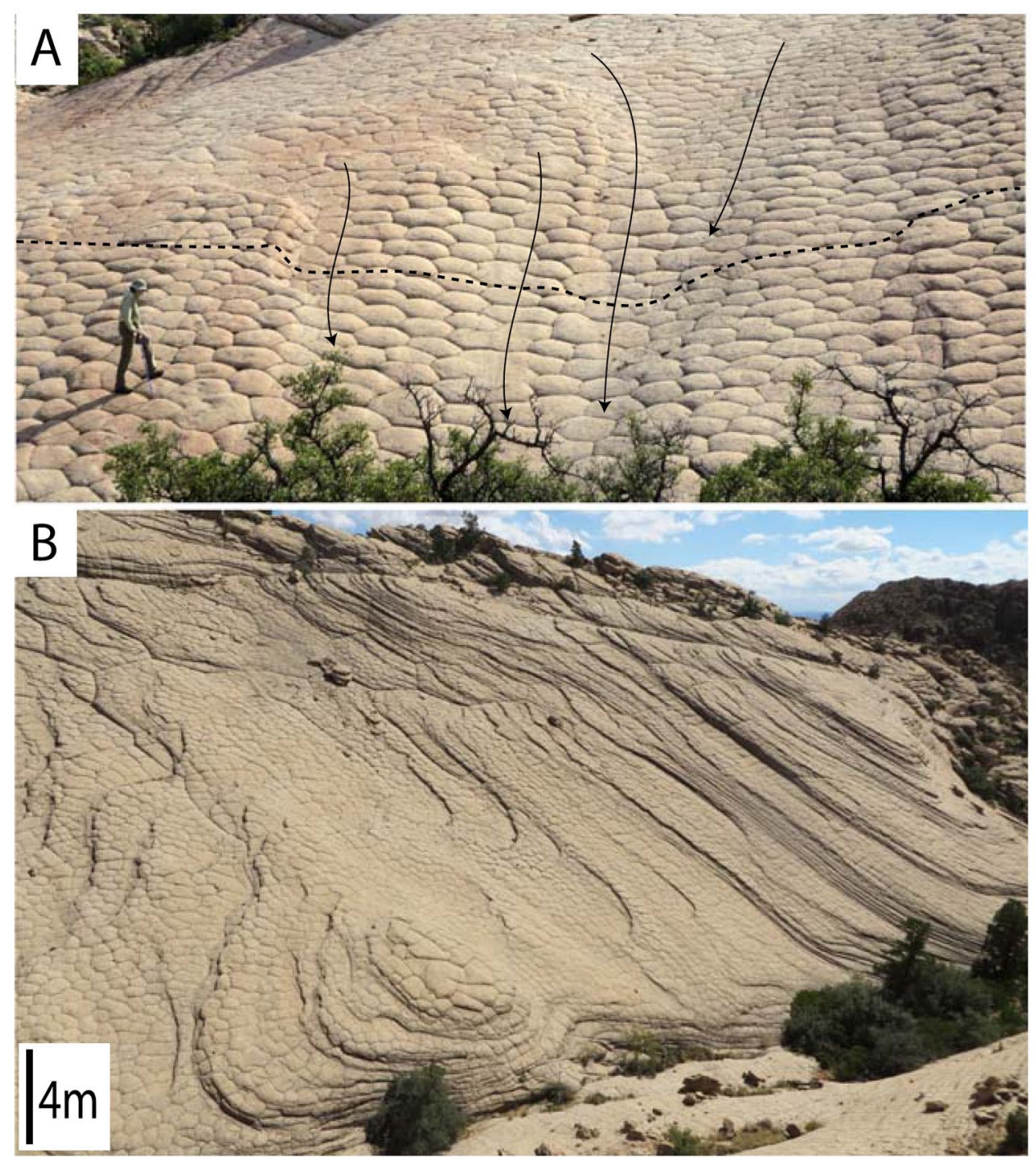

Figure 2. Hexagonal fracture patterns developed upon outcropping Navajo sandstone at the Yellow Knolls site (Figure 1). (A) Dashed line shows erosional relief on the dip slope of a single crossbed set. Erosion resulted from local runoff (arrows). (B) Hexagons are developed on exposed surfaces of more than a score of bedding planes within a single set of eolian crossbeds deposited by a large Jurassic dune.

starch (Jagla, 2002; Bohn et al., 2005; Goehring, 2008) and of columnar basalt (Ryan and Sammis, 1981; Weaire and O'Carroll, 1983; DeGraff and Aydin, 1987; Budkewitsch and Robin, 1994; Goehring, 2008) and sandstone (Velazquez et al., 2008) indicate that hexagonal fracture patterns do not form de novo at the surface. They instead evolve during repeated cycles of crack opening as cooling and drying gradients in lava and starch move deeper into the subsurface - the sequential 
fragmentation of Weaire and Hutzer (1999) and Jagla and Rojo (2002). Goehring et al. (2010) demonstrated that hexagonal mud cracks can evolve at the sediment surface if soft surface material is repeatedly wetted and dried. In each case, an original orthogonal pattern transforms into a hexagonal one: as new fractures open, they are imperfectly guided by the older fractures.

Although Loope and Burberry (2018) tied polygonal fractures in the Navajo sandstone to extensional stresses generated during buckling of sandstone slabs during formation of underlying, convex sheeting fractures, here we report evidence that requires rejection of that hypothesis. On broad, planar exposures in south-western Utah, we have found extensive, polygonal fracture patterns that are not closely associated with sheeting fractures. Patterns that are partially erased by granular disintegration definitively show that polygonal fracture patterns in the Navajo sandstone are not generated by buckling during subsurface formation of sheeting fractures.

In this article we describe, illustrate, and interpret the geometry and origins of sheeting fractures and polygons on Navajo sandstone outcrops, and report the first rock temperature data collected from thermal sensors installed in this formation. Both types of fractures form within $30 \mathrm{~cm}$ of the exposed rock surface - the zone where diurnal thermal cycling creates significant stress (Holzhausen, 1989; Collins et al., 2018). We conclude that the sheeting fractures in the Navajo sandstone (like those in Sierra Nevada granite) are driven by horizontal, compressive stress generated by rock expansion during the hottest days of summer; diurnal thermal cycles in the cooler months are much weaker. Eppes et al. (2016) showed that simple diurnal thermal cycles, if amplified by well-timed rainstorms, can lead to rock-cracking events. Our rock temperature data show that the greatest contractile temperature gradients (like the greatest expansive gradients) are generated during summer afternoons. The steepest contractile (cooling) temperature gradients coincide with monsoonal rainstorms. Measured winter rock temperature gradients are, in comparison, small.

Finally, we hypothesize that hexagon-dominated fracture patterns on Navajo sandstone outcrops are long-lived, evolved products of two interacting earth-surface processes: (1) granular disintegration that is steadily lowering friable bedrock on smooth, convex surfaces (Schumm and Chorley, 1966; Howard and Kochel, 1988); (2) cracking episodes triggered by rock-cooling rainstorms open conduits 
for water that simultaneously weakens the rock at the tips of propagating fractures. We propose that the hexagons in the sandstone are slowmoving, surficial analogs of hexagonal columnar joints that evolve below the surface of cooling basalt flows. A land-surface-generated cooling front (driven by repeated, diurnal thermal cycling and wetting events) passes (very, very slowly) through the rock mass as crack deepening and crack erosion simultaneously create new patterns in unfractured rock and destroy old patterns. These processes are now maintaining a hexagon-dominated pattern on stable rock surfaces, but on most steeper surfaces, mass wasting (guided by sheeting fractures) is preventing the initial rectilinear patterns (that formed at the land surface) from maturing into hexagonal patterns.

\section{Geologic, Geomorphic, and Climatic Context}

The Early Jurassic Navajo-Nugget-Aztec Sandstone (hereafter referred to as the Navajo sandstone) was deposited near the western margin of the supercontinent Pangea by desert dunes; its outcrops stretch from central Wyoming to southern Nevada and are particularly prominent across the Colorado Plateau. This well-sorted, homogeneous sandstone is up to $700 \mathrm{~m}$ thick, and is dominated by sets of crossbeds up to $30 \mathrm{~m}$ thick (Kocurek and Dott, 1983). The Navajo sandstone is a quartz arenite that, due to its high permeability and porosity (10-30\%; Parry et al., 2007), is an important aquifer and hydrocarbon reservoir. Schumm and Chorley (1966) concluded that convex slickrock slopes developed on Navajo sandstone are the result of relatively rapid, grain-by-grain weathering and erosion. Most of these slopes show only minor form control by bedding, and are weathering limited - the potential rate of transport is much higher than the rate at which debris is generated (Howard and Kochel, 1988).

According to Wong and Humphrey (1989), the Colorado Plateau has a moderate level of differential tectonic stress, but the absence of major faulting or seismicity within the Plateau interior led Zoback and Zoback (1989) to describe the differential stress levels there as 'generally low'. Sites in Manitoba, Texas, New England, Georgia and California where sheeting joints exist in granite have surface-level differential stress measurements ranging from 10 to $30 \mathrm{MPa}$ (Martel, 2017). 
No analogous measurements are available for comparisons with the Colorado Plateau. The tectonic stress required for sheeting joints to open is strongly influenced by dip and by topographic curvature the steeper the dip and the stronger the curvature, the less stress is required (Martel, 2017).

Diurnal temperature cycles cause stress to build in exposed bedrock where mechanical continuity with the deeper rock mass is maintained. Calculations by Holzhausen (1989) showed that daily rises of air temperature of more than $10^{\circ} \mathrm{C}$ above the mean air temperature produce sufficient tensile stress to open sheeting fractures at a New England granite quarry, but only at depths less than half a meter. At Escalante, Utah (Figure 1), the largest differences between mean monthly air temperatures and mean monthly highs and lows occur in June $\left(10.4^{\circ} \mathrm{C}\right)$ and smallest occur in December $\left(7.1^{\circ} \mathrm{C}\right)$; at St George, Utah, the largest difference also occurs in June $\left(7.9^{\circ} \mathrm{C}\right)$ and the smallest in December $\left(4.8^{\circ} \mathrm{C}\right.$ ) (https://www.ncdc.noaa.gov/cdo-web/datatools/normals) (Figure 3). Escalante receives $26 \mathrm{~cm}$ of precipitation annually. August is the wettest month, with a mean of $4.2 \mathrm{~cm}$. In late summer, the North American monsoon (https://en.wikipedia. org/wiki/ North_American_Monsoon) delivers heavy rain from afternoon thunderstorms. For Escalante, the summer of 2019 (with $2.6 \mathrm{~cm}$ of rain) was one of the driest in recent years. St George gets most of its annual 22 $\mathrm{cm}$ of precipitation in December through to March (12 cm; Figure 3). Climate data for Boulder and Escalante (Figure 3) indicate that, in winter, outcropping Navajo sandstone is likely to enter the frost cracking window (Anderson, 1998). Nightly freezing of the snowmelt that enters rock pore space during the day can play an important role in determining the rate of granular disintegration and landform denudation, especially at high elevation sites (Andersen et al., 2015).

Robinson (1970) showed that crossbedded Navajo sandstone at Zion National Park (south-western Utah) is, like most rocks, strong in compression (70 MPa) and weak in tension (3.0-1.2 MPa parallel to bedding; $1.0-0.5 \mathrm{MPa}$ perpendicular to bedding). For comparison, granite is much stronger (130 MPa in compression and 4.8 $\mathrm{MPa}$ in tension; Engineering Toolbox, https://www.engineeringtoolbox. $\mathrm{com} /$ material-properties-t_24.html). The geomechanical properties of rocks, however, are influenced not just by their composition and structure, but also by ambient and in situ conditions. Eppes et al. (2016) 

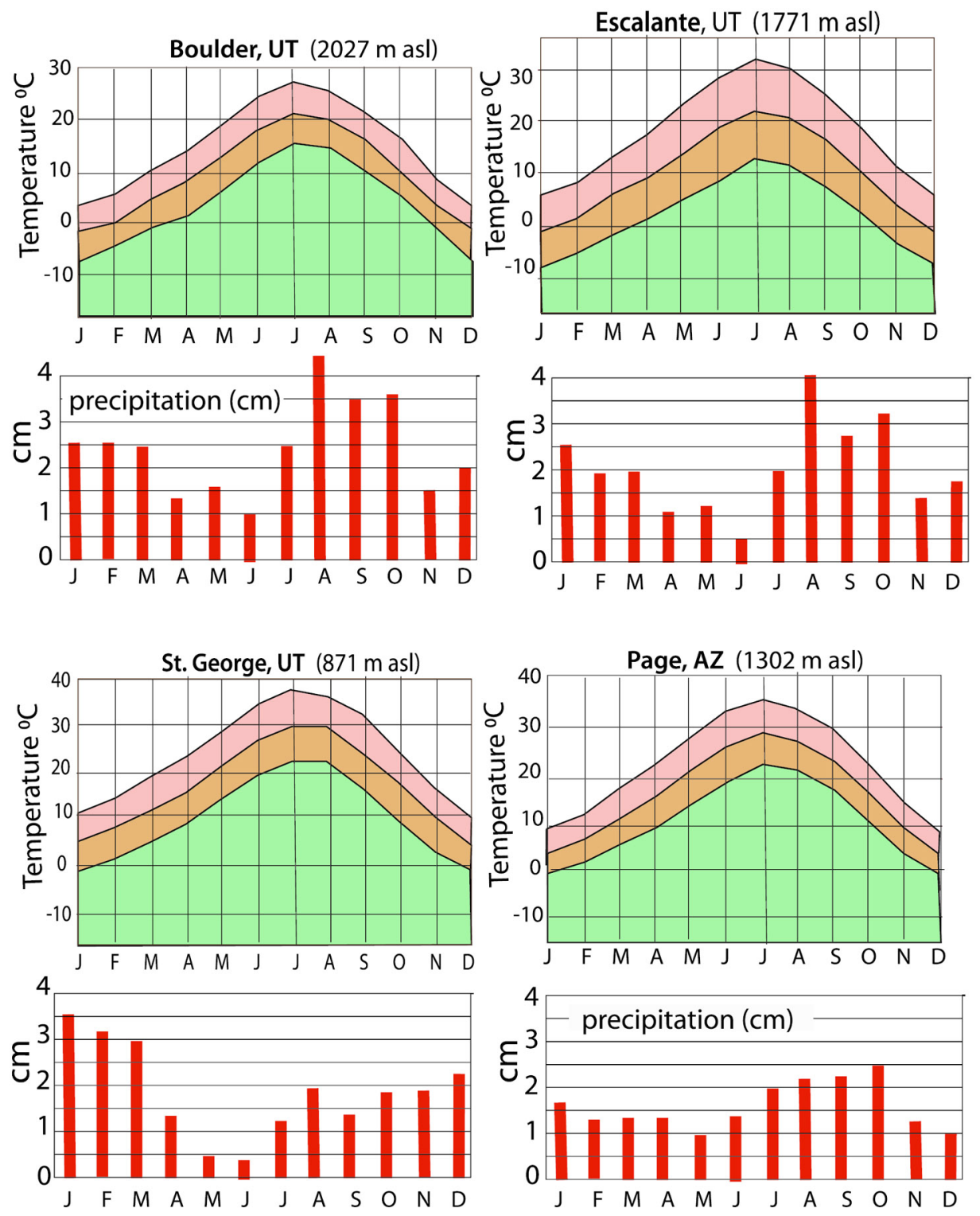

Figure 3. Monthly mean air temperatures and precipitation records from Boulder, Escalante, St George, and Page (1981-2010). Note that St George is warmer and gets less monsoon rain than the three Colorado Plateau stations. https://www.ncdc. noaa.gov/cdo-web/datatools/normals.

demonstrated that repeated, low-stress processes such as daily heating and cooling can set the stage for crack initiation and propagation. Further, they observed that most of the cracking events in the boulder they studied occurred when storms coincided with maximal, insolation-driven thermal stresses. Eppes and Keanini (2017) emphasized 
the importance of liquid water and water vapor in the mechanical breakdown of rock. Especially relevant to this study of the quartzrich Navajo sandstone are studies showing that water in the pores of sandstones causes reduction of rock strength via the replacement of silicon-oxygen-silicon bonds in silicate minerals with silicon-oxygen-hydrogen-hydrogen- oxygen bonds (Michalske and Freiman, 1982; Hadizadeh and Law, 1991). Studies by Wong et al. (2016), Guha Roy et al. (2017), and Zhou et al. $(2018,2019)$ concluded that fracture toughness of sandstone progressively decreases with increases of water content.

Advective and evaporative cooling by rainfall creates tensile stresses that can open cracks on impervious granite surfaces (Eppes et al., 2016). Wetting experiments carried out using simulated precipitation $(1.25 \mathrm{~cm}$ of water) on Navajo sandstone surfaces have shown that, after a 15-minute application, water had penetrated the rock as far as $7.5 \mathrm{~cm}$ (Schumm and Chorley, 1966). This means that, on bare sandstone outcrops, rapid infiltration of rainfall can: (1) generate tensile stress by rapidly cooling the uppermost portion of the exposed bedrock and (2) simultaneously diminish the tensile strength of the rock (Zhou et al., 2018), not only immediately below the general surface but also along pre-existing fractures.

\section{Monitoring of Subsurface Rock Temperatures}

Using Onset $\mathrm{HOBO}$ dual temperature data loggers (Onset $\mathrm{HOBO}$ MX2303, Onset Computer Corporation, Bourne, MA) at three southern Utah sites (Head of the Rocks; 1730 m above sea level (a.s.l.); Burr Trail, $1813 \mathrm{~m}$ a.s.l.; and Sand Cove, $1246 \mathrm{~m}$ a.s.l.; Figure 1), we collected sandstone temperature data at $2 \mathrm{~cm}$ and $15 \mathrm{~cm}$ depths at 10 and 15-minute intervals for 7.5 months (July 28, 2019 to March 12, 2020). Each sensor (composed of a thermistor enclosed in 4-mm-diameter, 4-cmlong, steel probe and attached to a thin, flexible cable) was installed at the terminus of a $6 \mathrm{~mm}$-diameter, horizontal hole (between 20 and $40 \mathrm{~cm}$ long) cut into sloping rock surface with a hand-held hammer drill. We emplaced each sensor beneath a bare rock surface sloping less than $10^{\circ}$ and broadly open to the sky (unshaded by vegetation or nearby outcrops). Plumber's putty was used to secure the cable/probe and to reduce the air space behind the sensor. 


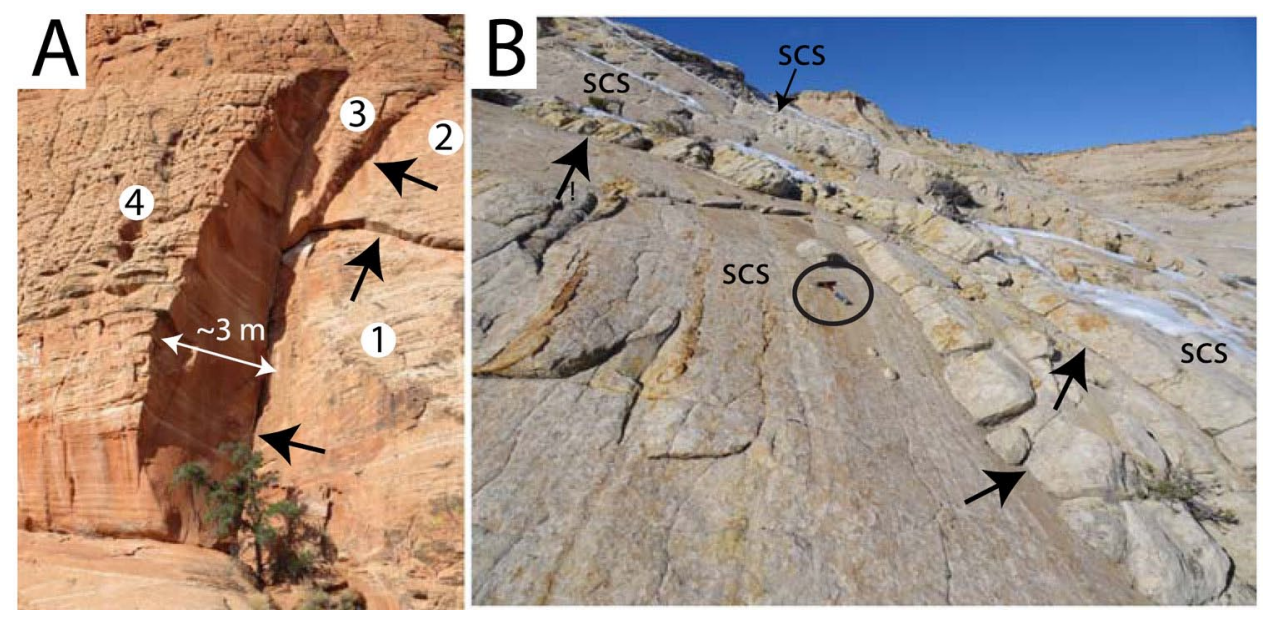

Figure 4. Sheeting fractures in Navajo Sandstone. (A) Three sheeting fractures (black arrows) and four rock surfaces exposed at Sand Cove (Figure 1). Each rock surface was exposed by mass wasting along a sheeting joint. Surface 1 is the youngest and surface 4 is the oldest. Note the development of surficial, rectilinear fracture patterns on surface 4 . The 3-m-thick slab shows that sheeting joints can form at least $3 \mathrm{~m}$ from the land surface. (B) Four smooth, convex land surfaces (SCS) exposed by weathering of the rock slabs above each of four sheeting joints (arrows); hammer for scale is circled; Head of the Rocks site (Figure 1).

\section{Fractures on Outcrops: Description}

\section{Sheeting joints}

Sheeting joints are abundant at all of our study areas and typically appear on broadly convex land surfaces (Howard and Kochel, 1988). Sandstone slabs defined by these fractures range from a few centimeters to at least $3 \mathrm{~m}$ thick; the most abundant slabs are 15 to $20 \mathrm{~cm}$ thick (Figure 4).

Bradley (1963) reported that tunnels drilled into near-vertical canyon walls of Navajo sandstone at the site of the Glen Canyon dam (central Colorado Plateau; Figure 1) encountered sheeting fractures as much as $9 \mathrm{~m}$ inward from the rock surface. Sheeting fractures that cut bedding surfaces at a high angle are especially common on ridges and domed landforms, and, on the steepest exposures, these sheeting fractures control most mass-wasting events (Figure 4A). 


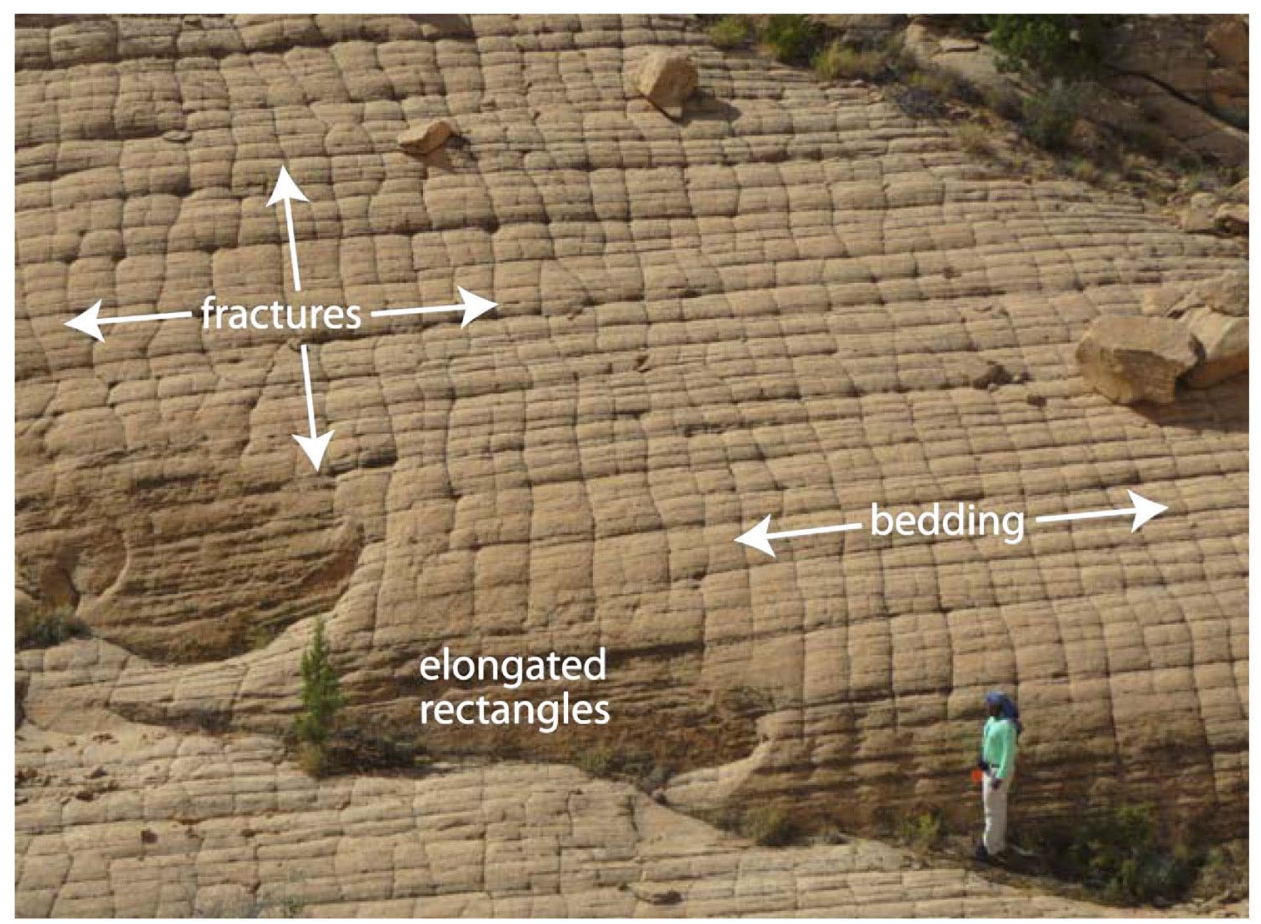

Figure 5. Orthogonal, rectilinear fracture pattern oriented perpendicular to bedding planes. All strata dip away from the viewer at $\sim 15^{\circ}$ and are part of the same thick set of crossbeds. Rectilinear polygons are defined by Tand X-vertices; one set of surficial fractures is oriented along the exposed bedding (parallel to contours) and the other set is oriented perpendicular to bedding planes (perpendicular to contours). Yellow Knolls site (Figure 1).

\section{Orthogonal (Tand X-dominated) fracture patterns}

As noted by Howard and Kochel (1988, pp. 8-9), few Navajo sandstone erosional surfaces are oriented parallel to bedding. An overwhelming majority of the orthogonal fractures in our study area appear on slopes steep enough to cut crossbedding ( $>20^{\circ}$; Figure 5), but they also are present on some near-horizontal land surfaces that cut steeply dipping crossbeds. These fractures usually delineate vertically elongated rectangles, with one set of fractures oriented parallel to exposed bedding planes and a second set perpendicular to bedding. Most of these fractures are straight, but some display significant deviations near vertices. Spacings of the fractures perpendicular to bedding range from about $40 \mathrm{~cm}$ to about $60 \mathrm{~cm}$, and some individual fractures extend upslope more than $5 \mathrm{~m}$ before terminating 
at a bedding plane. Because the Navajo sandstone is composed of stacked sets of crossbeds, fractures on steep outcrops oriented perpendicular to the apparent dip shift abruptly as they pass from one set of crossbeds to the next (Chan et al., 2008).

\section{Hexagonal (Y-dominated) patterns}

At one of our study sites (Yellow Knolls; Figure 1), hexagon-dominated fracture networks are broad $\left(>5000 \mathrm{~m}^{2}\right)$ and remarkably uniform on planar surfaces parallel to Navajo crossbeds (Figures 2, 6). Hexagonal patterns at the Sand Cove and Buckskin Gulch sites (Figure 1) differ from most of those at the Yellow Knolls site (Figure 2), in that they have developed on steep slopes and domes and cut across many crossbeds. At these sites, clusters of in situ, bulbous sandstone masses, bounded by hexagonal fractures and averaging

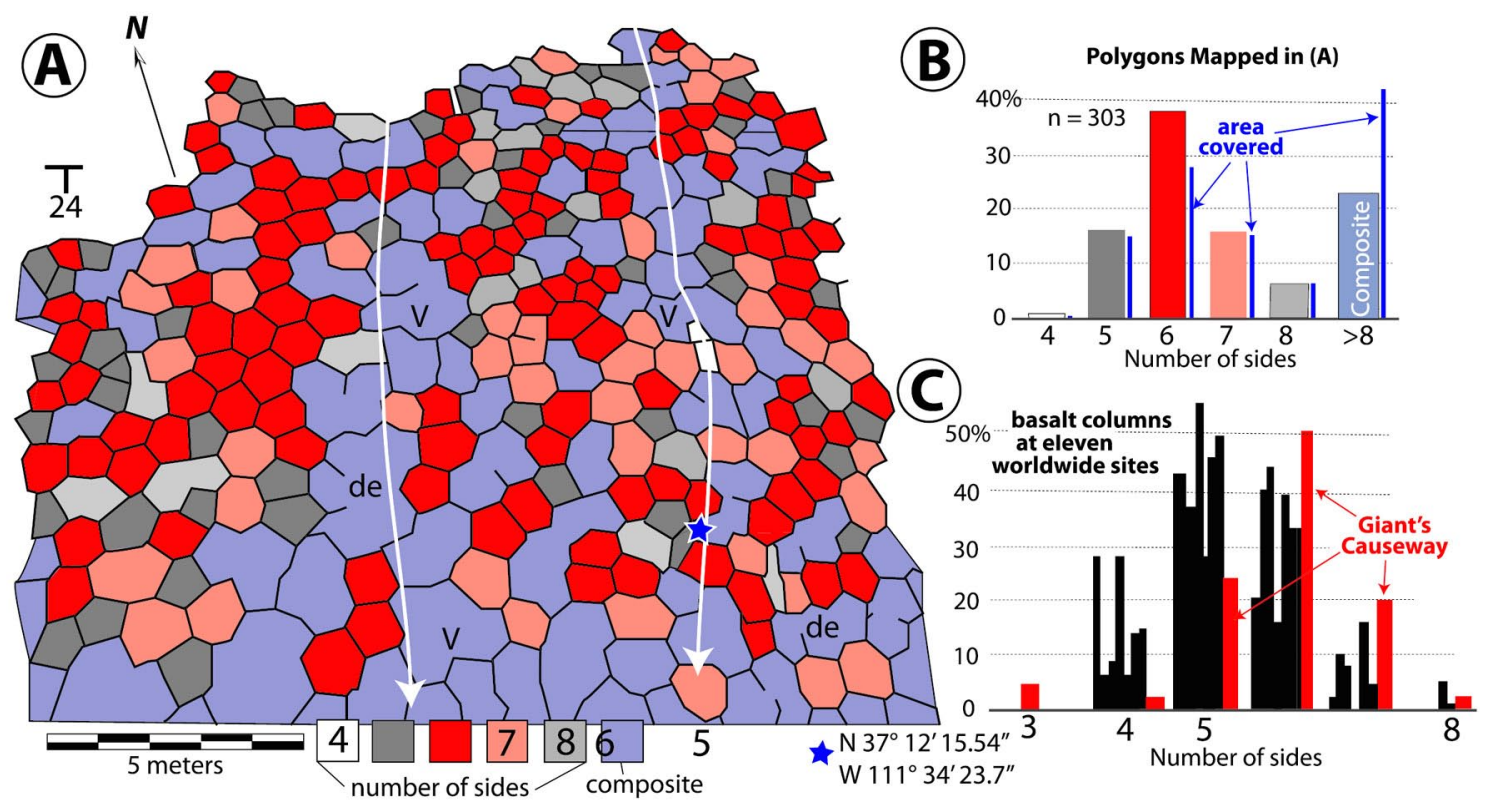

Figure 6. (A) Map of polygons at Yellow Knolls (Figure 1) traced from a low-elevation aerial photograph oriented perpendicular to the south-southwestdipping rock slope. Representative dead-end fractures (de) and V-vertices $(V)$ are labeled. White lines show flow paths of runoff (see Figure 2A). (B) Histogram based on (A). (C) Polygon shapes from basalt flows (from Beard, 1959; Budkewitsch and Robin, 1994). If the composite polygons in (B) are dismissed, the shapes of the mapped polygons correspond closely to shapes of basalt columns at Giant's Causeway, Northern Ireland. 


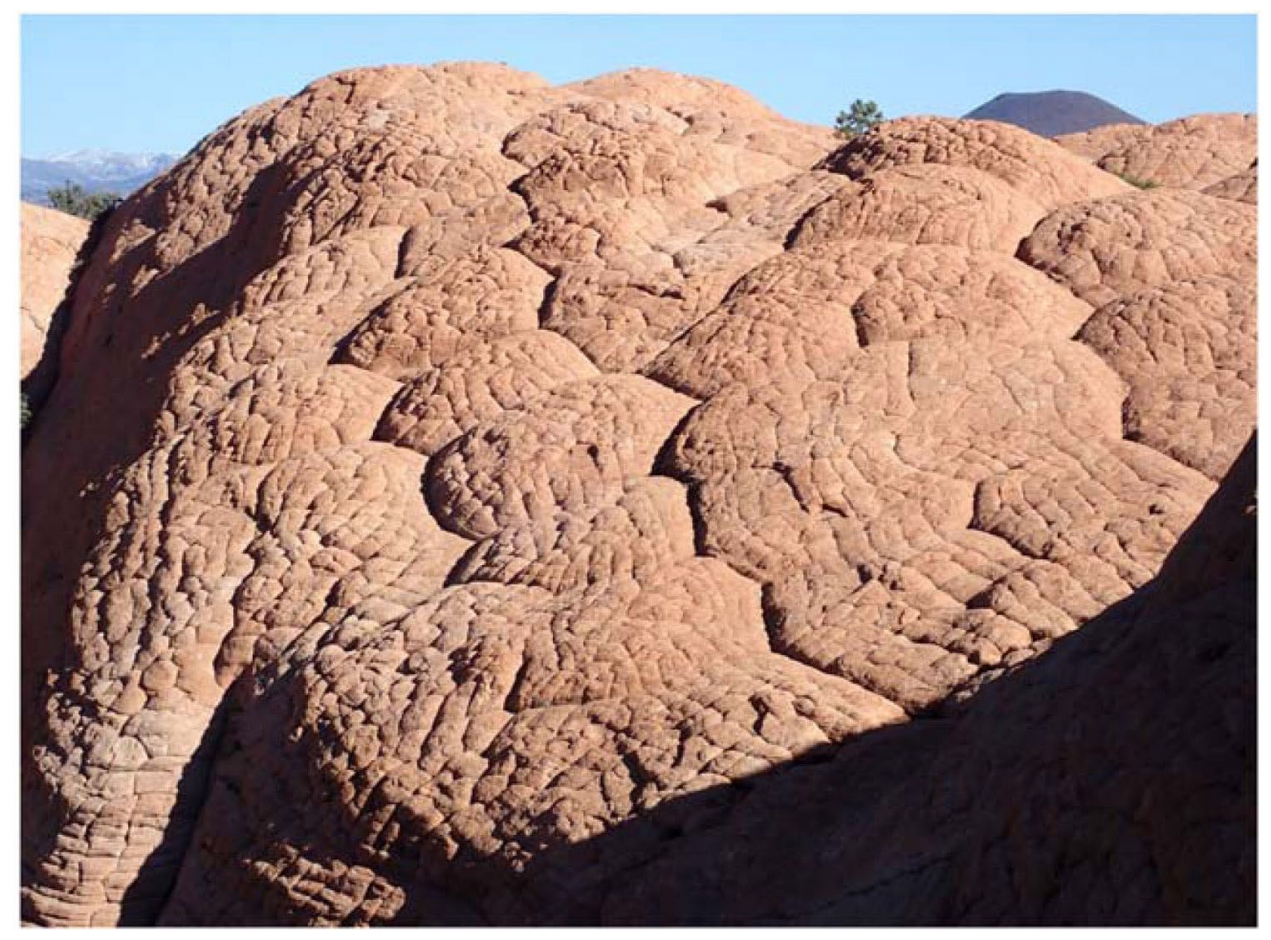

Figure 7. Bulbous sandstone outcrop at Sand Cove (Figure 1). Large-scale (5 mdiameter), hexagonal fracture pattern in which individual hexagons are further divided into a mixture of hexagonal and rectilinear polygons. During rainstorms, cracks defining the perimeters of the large hexagons receive copious runoff (Loope and Burberry, 2018, figure 14).

$5 \mathrm{~m}$ in diameter, develop on many broad domes and rounded ridges (Figure 7; Howard and Kochel, 1988; Loope and Burberry, 2018, figures 2 and 6).

The hexagons that dominate the Yellow Knolls dip-slopes (Figures 1 , 2) range from $20 \mathrm{~cm}$ to $1 \mathrm{~m}$ in diameter (Figure 6); individual polygons have domed upper surfaces with $\sim 10 \mathrm{~cm}$ of relief. We have found very few planar-topped (non-domed) hexagons. Depth of the fractures is difficult to measure. Many are at least $20 \mathrm{~cm}$ deep, and some propagated downward along curving paths. Of the 303 contiguous polygons that we mapped from an aerial photograph (Figure $6 \mathrm{~A}),<1 \%$ are four-sided, $16 \%$ are five-sided, $38 \%$ are six-sided, $16 \%$ are seven-sided, $6 \%$ are eight-sided, and $23 \%$ have more than eight sides (mapped as 'composites'; Figure 6A,B). The latter are the largest polygons; they together comprise $42 \%$ of the mapped area (Figure $6 \mathrm{~B}$ ). Composite polygons are bounded by the straight segments 
of adjacent hexagons. The straight, bounding segments commonly meet at obtuse angles approaching $120^{\circ}$ (Figures 6B, 8). Fractures connecting these $\mathrm{V}$-vertices also separate adjoining large polygons (Figure 8B). 'Dead-end' fractures terminate within the large polygons (Figure 6A). The lengths of dead-end fractures coincide closely with the lengths of the fractures that define adjacent hexagon segments (Figure 6A).

\section{Results and Interpretation}

\section{Thermal cycles}

If a body that undergoes temperature change is prevented from contracting or expanding, thermal stress arises within that body. The thermal stress that results from diurnal heating and cooling is proportional to the subsurface temperature gradient (defined by the temperature difference between the two sensors at the same time divided by the distance between the sensors $[13 \mathrm{~cm}])$. The steeper the temperature gradient, the greater the thermal stress. We use the term expansive temperature gradient when the shallow $(2 \mathrm{~cm})$ probe is warmer than the deep $(15 \mathrm{~cm})$ probe, and contractile temperature gradient when the shallow probe is cooler than the deep probe. Expansive temperature gradients generate surface-parallel, compressive stress and tensile stress perpendicular to curved rock surfaces, and can thereby initiate and drive sheeting fractures (Holzhausen, 1989; Martel, 2017). Contractile temperature gradients generate surface-parallel, tensile stress and have the potential to produce fractures that open and propagate at a high angle to the rock surface (Riley et al., 2012).

At all three of our monitored sites, the greatest temperature gradients between the $2 \mathrm{~cm}$ (shallow) and $15 \mathrm{~cm}$ (deep) sensors occurred on summer afternoons (Figures 9, 10, 11). Summer temperature data record both the greatest positive (expansive, shallow sensor warmer) gradient (Sand Cove; $0.78{ }^{\circ} \mathrm{C} / \mathrm{cm} ; 10.2{ }^{\circ} \mathrm{C}$ difference) and the greatest negative (contractile, shallow sensor cooler) gradient (Head of the Rocks; $0.66^{\circ} \mathrm{C} / \mathrm{cm} ; 8.7^{\circ} \mathrm{C}$ difference). In the absence of precipitation, the recorded rock temperature gradients at our three monitoring sites generally coincide with the differences between monthly air temperature means and minima, in that the greatest thermal stress is likely to 

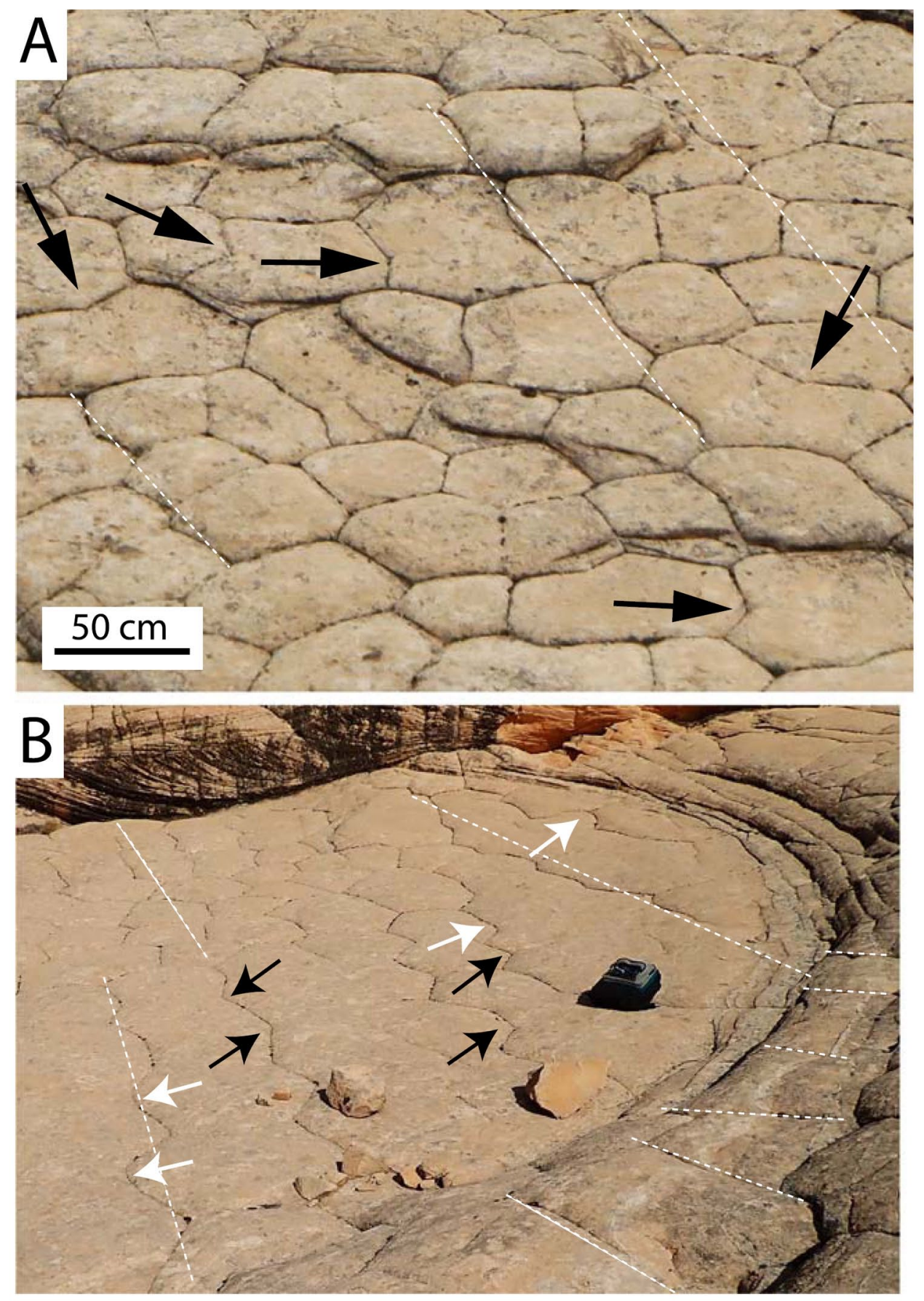

Figure 8. Rock surface displaying characteristics of both orthogonal and hexagonal patterns, with trends (white, dashed lines) of zig-zagging fractures lining up with trends of straight fractures (Yellow Knolls, Figure 1). (A) Arrows point to V-vertices in composite polygons. Interpreted as an evolved pattern in which each vertex along originally straight fractures with T-vertices migrated in the direction shown by its arrow (see text). Erosion of slow-propagating fractures led to erasure of one fracture from each vertex. (B) Highly elongate polygons with perimeters defined by $\mathrm{V}$-vertices (black arrows) and curved, U-vertices (white arrows). Day pack for scale. 


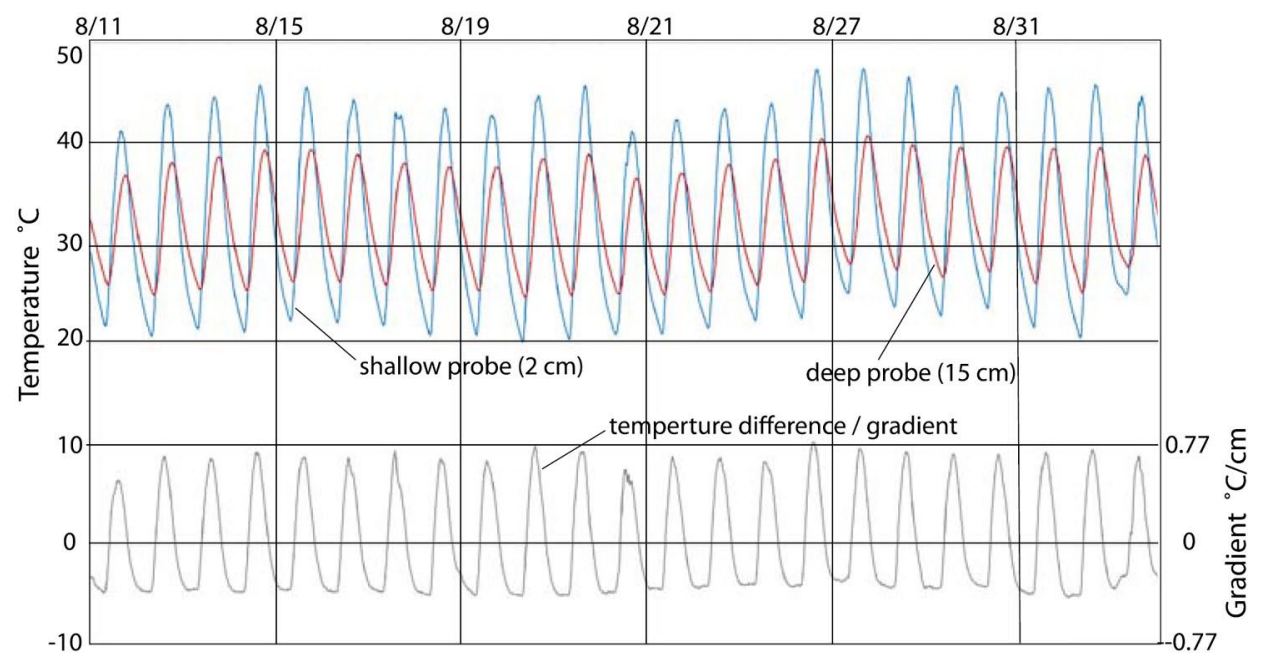

Figure 9. Late August rock temperature data from the two sensors installed at the Sand Cove site (Figure 1), $22 \mathrm{~km}$ northwest of the St George, UT weather station. Diurnal cycles shown by the shallow sensor represent the greatest temperature fluctuations recorded in this study, $\sim 25^{\circ} \mathrm{C}$. Vertical bars mark every fourth midnight. Note that the temperature differences (gray line) between the two sensors (at the same time) are greater during the heat of the day $\left(\sim 10^{\circ} \mathrm{C}\right)$ than in early morning $\left(<5^{\circ} \mathrm{C}\right)$.

be generated in summer (Figure 3). Whereas the strongest expansive gradients occurred on clear days when both shallow and deep temperatures were peaking, the strongest contractile gradients occurred during afternoon monsoonal rainstorms when neither sensor was recording maximum or minimum temperatures (Figure 10).

\section{Origins of surficial fractures}

Given their distribution, the rock temperature data, and the low rock strength, the simplest and best interpretation of the shallow fractures on Navajo sandstone outcrops (including the sheeting fractures as well as the polygonal fracture patterns) is that they were triggered by thermal stress. Shallow sheeting fractures (Bradley, 1963; Loope and Burberry, 2018) in the Navajo sandstone (including those that are interlaced with polygons) were triggered by rock expansion; the polygonal fractures perpendicular to the land surface were formed via rock contraction. 


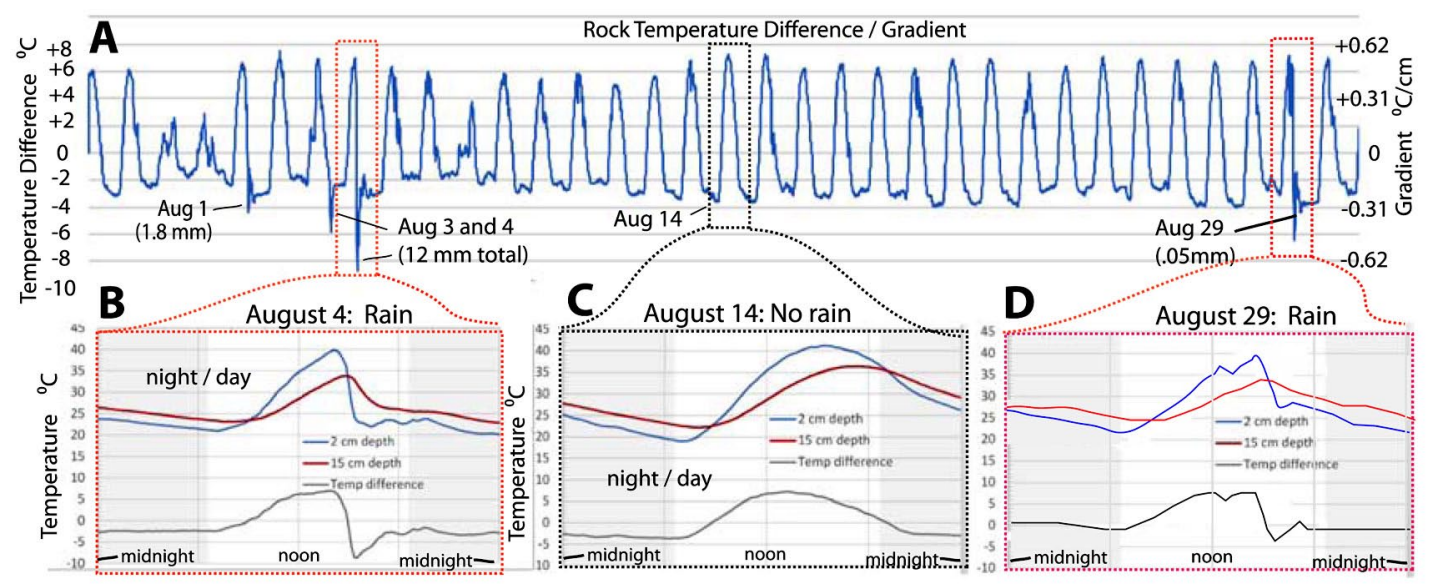

Figure 10. Thermal data from the Head of the Rocks study site, $14 \mathrm{~km}$ east-southeast of the Escalante weather station (Figures 1 and 3 ). During thetime interval shown in (A) (July 28-August 30, 2019), the station recorded three days with rainfall - August 2 (1.8 mm), August 4 (12 mm), and August $29(0.1 \mathrm{~mm})$. The thermal sensors at Head of the Rocks show four abrupt cooling patterns that we associate with four distinct rainfall events - August 1, August 3, August 4 (B), and August 29 (D). Radar imagery shows that the August 1 rain fell in mid-afternoon, but the August 3 (Figure $11 \mathrm{~A}$ ) rain began no earlier than 8:30 p.m., and was included in the $12-\mathrm{mm}$ total in the weather station record, along with the August 4 rain event. Note that rapid temperature drops (downward spikes in $(A)$ were recorded for all four (relatively minor) rain events and led to greater temperature differences $\left(4.3^{\circ} \mathrm{C}, 5.7^{\circ} \mathrm{C}\right.$, $8.6^{\circ} \mathrm{C}, 6.4^{\circ} \mathrm{C}$, and therefore more contractile stress) than was reached on any rainless days by slow overnight cooling, for example (C), August $\left.14 ; 3.6^{\circ} \mathrm{C}\right)$. The shallow-rock temperature change on the afternoon of August 4 (B) was the most rapid recorded in this study $\left(15.3^{\circ} \mathrm{C} / \mathrm{h}\right.$ between $2: 20$ and 3:20 p.m. mountain daylight time [MDT]). For comparison, on August 14 (C) the highest (dry, evening) cooling rate was $3.4^{\circ} \mathrm{C} / \mathrm{h}$ (between 7:00 and 8:00 p.m.).

\section{Sheeting fractures}

Following the work of Collins et al. (2018) on granite domes in California, we conclude that both thermal and regional tectonic stresses contributed to the origin of sheeting fractures in the Navajo sandstone. The deepest sheeting fractures (up to $50 \mathrm{~m}$ in some localities; Martel, 2017) develop far below the depths of strong diurnal thermal cycling (Holzhausen, 1989; Collins et al., 2018), and are almost exclusively driven by tectonic stress. The compressive tectonic stress at the California site ( $15 \mathrm{MPa})$ is likely greater than that of the (nearly aseismic) Colorado Plateau (Zoback and Zoback, 1989). The 9-m-deep 

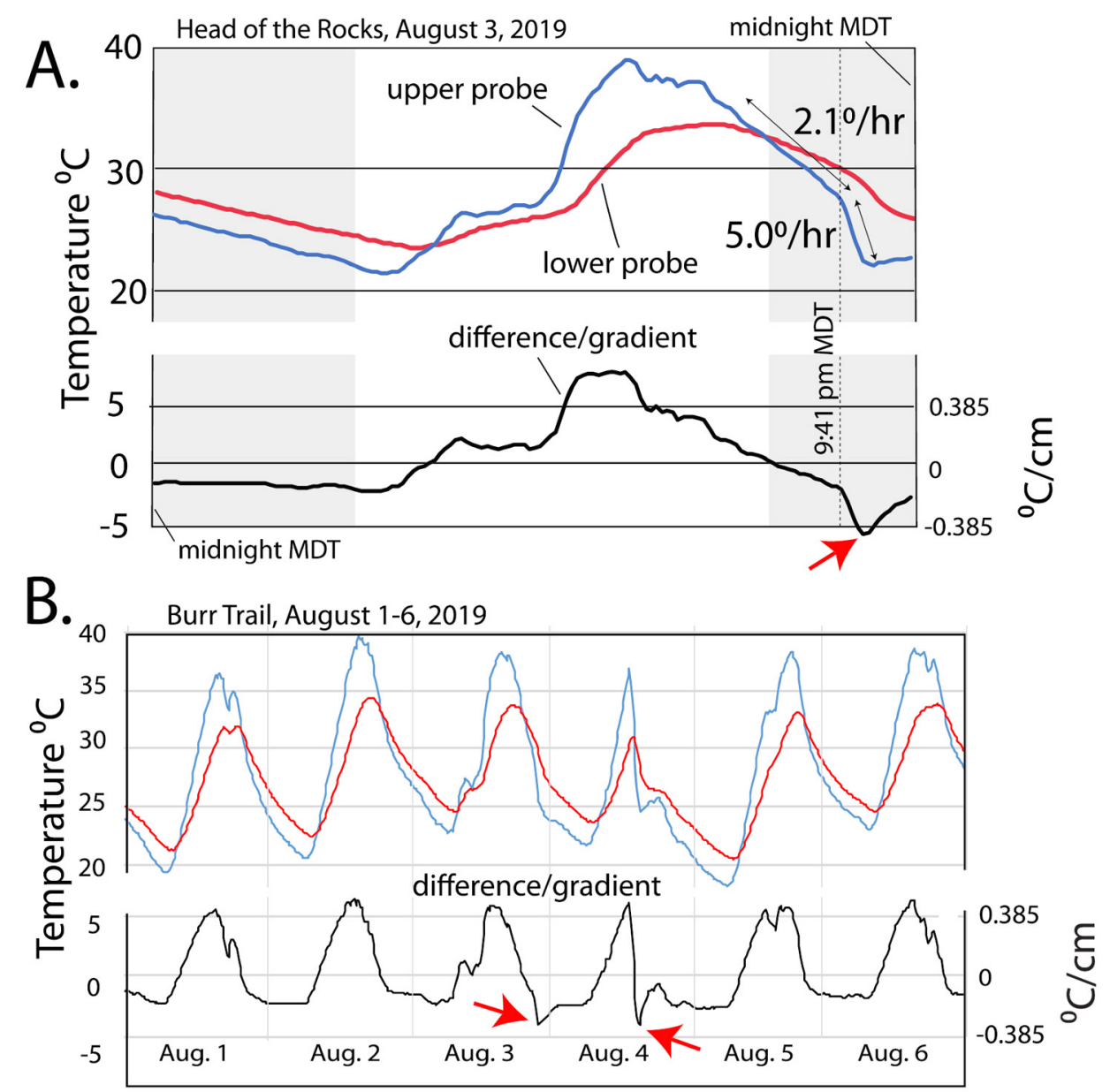

Figure 11. Attenuation of rainfall-induced temperature differences. Small, downward-directed spikes in the difference plots (red arrows) were (as in Figure 10) caused by rapid cooling of the rock by rain. (A) At 9:40 p.m. on August 3, a rainfall event increased the cooling rate of the upper probe by $250 \%$, but generated only a small spike relative to those of two storms shown on Figure 10(B, D), because (unlike the other two) this storm arrived after the shallow probe had cooled for four hours. (B) The spike recorded August 3 at Burr Trail (13 km northeast of Head of the Rocks) was caused by the same evening storm shown in (A); its small magnitude is also likely due to the late hour of storm arrival. On August 4, a much smaller spike resulted at Burr Trail from the same afternoon storm that recorded the largest spike at Head of the Rocks (Figure 10B). At Burr Trail, heating by post-clearing insolation led to a rise of temperature of the shallow probe and a slowing of cooling of the deep probe; both these changes attenuated the temperature difference between the probes. 
sheeting joints reported from the Navajo sandstone at Glen Canyon dam (Bradley, 1963) demonstrate, however, that Colorado Plateau tectonic stresses can generate deep sheeting fractures behind steep $\mathrm{Na}$ vajo sandstone cliff faces, where gravitational stress provides little resistance to fracture opening. Strong curvature of the land surface greatly reduces the compressive stress required for sheet fracturing ( $k$ [in $\mathrm{m}^{-1}$ ] in figure 4 of Martel, 2006). The shallow sheeting fractures developed on relatively small Navajo landforms (Figure 4B; Loope and Burberry, 2018, figures 2, 6 and 12) are much more strongly curved $\left(k\right.$ [in $\left.\left.\mathrm{m}^{-1}\right]\right)$ between 0.61 and 0.063 ) than those reported from granite outcrops (Martel, 2006, figure 4). Stress induced by thermal cycling likely played a large role in the origin of these fractures, in both weakening the rock and triggering rock failure.

Larger Navajo landforms (Figure 4A; Bradley, 1963) are nearer to the scale of those in California and their deeper, broader sheeting joints have lower curvature. Thermal cycling likely contributed a small portion of the compressive stress required to open those fractures, but based on studies of cracks in California granite (Stock et al., 2012; Collins and Stock, 2016; Collins et al., 2018), their role as a trigger should not be ignored.

Strong thermal cycling and rapid water infiltration make the shallow-subsurface Navajo sandstone especially susceptible to subcritical fracturing and stress corrosion (Heap et al., 2009; Eppes et al., 2016). The $20-25^{\circ} \mathrm{C}$ rock-temperature fluctuations at Sand Cove (Figure 9) are similar to those measured by Collins et al. (2018) in California granite just prior to the rock's energetic fracture. For this study, the highest rock temperature $\left(47.4^{\circ} \mathrm{C}\right.$ at $3: 30$ p.m. on August 26), the largest diurnal temperature fluctuation $\left(24.9^{\circ} \mathrm{C}\right.$ on August $\left.26-27\right)$, and highest rate of rock temperature rise $\left(8.5^{\circ} \mathrm{C} / \mathrm{h} ; 10: 00-11: 00\right.$ a.m, August 26) were recorded at Sand Cove (the lowest-elevation monitoring site). The steepest measured, expansive temperature gradient $(0.78$ ${ }^{\circ} \mathrm{C} / \mathrm{cm} ; 10.1{ }^{\circ} \mathrm{C}$ difference) developed on August 26 at 2:00 p.m. This gradient is comparable to that of the steepest gradient measured by Collins et al. (2018, figure 5a) in California granite (also measured on the hottest days of the year). Differential rock expansion during California heat waves in June and July of 2016 (Collins et al., 2018) produced sufficient compressive (parallel to the land surface) and tensile stresses (perpendicular to convex land surfaces; Martel, 2017) to 
not only weaken the granite and drive fracture propagation (Eppes and Keanini, 2017), but also to eventually trigger explosive rock failure (Collins et al., 2018). Although sheeting fractures are abundant and widespread in the Navajo sandstone, the only evidence we have seen of explosive failure is an 'A-tent' surrounded by fresh rock debris (Loope and Burberry, 2018, figure 4).

\section{Orthogonal-rectilinear (Tand $X$-vertex dominated) fracture patterns}

Orthogonal-rectilinear patterns are extensively developed on cliffs and steep, smooth slopes where many planes of weakness (bedding planes) are exposed. The parallelism of bedding planes within a set of crossbeds guides development of an orthogonal fracture pattern within that set; this pattern shifts at each boundary between adjacent crossbed sets. Because exposed bedding planes present the weakest potential pathway for initiation and propagation of surface fractures, fractures that follow bedding likely form first, relieving contractile stresses oriented perpendicular to their trend; the remaining stress is relieved by the more prominent fractures that abut the bedding-parallel fractures (Chan et al., 2008). The lateral continuity of many of the fractures oriented perpendicular to bedding planes on the steepest slopes (Figure 5) suggests that, when these fractures were propagating, open fractures parallel to bedding were short and few in number. Because the gravitational force resisting the opening of beddingparallel fractures on steep slopes is great (relative to that on lower slopes), we infer that after initiation and propagation, most of these are held tightly closed, allowing bedding-perpendicular fractures to propagate across them, forming numerous ' $X$ ' vertices (Figure 5 ). Although fracture patterns on many outcrops are easily categorized as orthogonal or hexagonal (Figure 5), there are also many outcrops that display the characteristics of both (Figure 8): Individual, straight fractures with T-vertices can abruptly change into zig-zagging lines of the same trend with $\mathrm{Y}$-vertices.

Hexagonal (Y-dominated) fracture patterns

Hexagonal patterns are present on many Navajo sandstone outcrops across southern Utah, and are especially well developed on homogeneous outcrops where bedding was obliterated during the Jurassic by burrowing or liquefaction (Loope and Rowe, 2003; Chan et al., 2008; Bryant et al., 2013; Loope and Burberry, 2018). The broad, planar 
hexagonal patterns displayed at Yellow Knolls, however, are highly unusual. As noted by Howard and Kochel (1988), few Navajo outcrops are controlled by bedding; the rarity of broad hexagonal patterns is related to the rarity of slopes developed parallel to bedding. So, in contrast to the orthogonal-rectilinear patterns, extensive hexagonal patterns are best developed on outcrop surfaces where few planes of weakness (bedding planes) are exposed (Figure 2).

Contractile temperature gradients (deep sensor warmer than shallow sensor; Figure 10) generate stress parallel to the land surface that can open cracks perpendicular to the land surface. At the Sand Cove site, maximum temperature differences in August ranged from 3.7 to $5.2^{\circ} \mathrm{C}$, usually recorded after cool nights, just before sunrise (Figure 9); the strongest measured temperature difference and temperature gradient $\left(5.7^{\circ} \mathrm{C}\right.$ and $0.44^{\circ} \mathrm{C} / \mathrm{cm}$ ) occurred on September 9 . Among all study areas, the greatest measured contractile temperature difference and gradient $\left(8.7^{\circ} \mathrm{C}\right.$ and $0.67{ }^{\circ} \mathrm{C} / \mathrm{cm}$ ) were recorded at the Head of the Rocks site (14 km east-southeast of Escalante, Utah) at 3:20 p.m., August 4,2019 . The shallow rock temperature record showed a midafternoon drop from $39.6^{\circ} \mathrm{C}$ at 2:20 p.m. to $24.3^{\circ} \mathrm{C}$ at 3:20 p.m. (Figure 10). The same day, the weather station for the town of Escalante recorded 0.5 inches $(12 \mathrm{~mm})$ of rain. This measurement, however, also included rainfall from a storm that struck the evening of August 3. NOAA (National Oceanic and Atmospheric Administration) radar imagery (national reflectivity mosaic) shows strong precipitation over the site on both August 3 and August 4: https://gis.ncdc.noaa.gov/ maps/ncei/radar. Data from the upper sensor at the Burr Trail site for August 3 (Figure 11) shows a $12.4{ }^{\circ} \mathrm{C}$ temperature drop between 2:20 and 4:00 p.m. Rock temperature started to rise at 5:00 p.m., probably due to clearing of the sky and insolation, limiting the maximum temperature difference to $4.1^{\circ} \mathrm{C}$ (at 4:00 p.m.).

Lachenbruch (1962) gives the following equation for the calculation of horizontal thermal stress: where $Y$ is Young's modulus, $v$ is Poisson's ratio, $\alpha$ is the coefficient of linear expansion and $\theta$ is the diurnal temperature range in Kelvin. Using this equation, a Young's modulus of $20 \mathrm{GPa}$, a Poisson's ratio of 0.3 (Aydin and Johnson, 1983), a coefficient of linear expansion of $1.3 \times 10^{-5} \mathrm{~K}^{-1}$, and the largest diurnal temperature fluctuation above the mean temperature for the day at $2 \mathrm{~cm}$ depth $\left(+12.4^{\circ} \mathrm{C}\right.$; Sand Cove; August $26-27$; Figure 9), we calculate that 
the greatest horizontal, compressive thermal stress is approximately +4.6 MPa. The greatest contractile stress (using $12.1^{\circ} \mathrm{C}$; Head of the Rocks, August 4-5; Figure 10) is approximately 4.5 MPa (see Holzhausen, 1989, p. 265).

We take the calculated stresses to be sufficient to open and drive fractures in the Navajo sandstone (tensile stress < $3 \mathrm{MPa}$; Robinson, 1970), especially considering the weakening of surficial sandstone by long-term exposure to (dry) diurnal temperature cycling prior to fracture. The conditions on hot, clear summer days at Sand Cove (Figure 9) are optimal for initiating and driving sheeting fractures, and the conditions at Head of the Rocks (Figure 10B,D) are the best for initiating and driving polygonal fractures because: (1) the magnitudes of the stresses are greatest; and (2) the temperatures are changing most rapidly ( +8.5 and $15.3^{\circ} \mathrm{C} / \mathrm{h}$ ). Further, due to the chemophysical processes made possible by porewater, cracks can, when water is present, propagate to depth at a lower level of stress because there is differential stress concentration at their tips (Michalske and Freiman, 1982; Hadizadeh and Law, 1991; Eppes and Keanini, 2017; Collis et al., 2018).

Data from the Head of the Rocks and Burr Trail sites provide good examples of how relatively rare wetting events can produce steeper contractile thermal gradients than do the daily, dry thermal cycles $\left(0.33^{\circ} \mathrm{C} / \mathrm{cm}\right.$; maximum difference, $4.3^{\circ} \mathrm{C}$; Figures $\left.9,10,11\right)$, as well as the greatest rates of temperature change. We did not recognize any wetting events with similar signatures in the Sand Cove thermal record - largely because no rain fell there between July 1 and November 20 (Figure 12). A November 20-21 storm delivered $3.4 \mathrm{~cm}$ of rain at St George, Utah - nearly triple the amount that fell on August 3 and 4 at Escalante and Head of the Rocks. Despite the high volume of water, this Sand Cove wetting did not generate steep contractile temperature gradients (Figure 12) perhaps because, prior to wetting, rock surfaces were much cooler, and because during the late Fall and Winter months, the rate of precipitation from large-scale frontal systems is low (https://www.climas.arizona.edu/sw-climate/temperatureand-precipitation ).

Temperature fluctuations and contractile temperature gradients diminished with the coming of winter; temperature differences between the sensors at our Burr Trail site fell to very near $0{ }^{\circ} \mathrm{C}$ following a snowstorm. This interval records multiple freeze-thaw cycles - the zero-curtain (Figure 12; Outcalt et al., 1990; Matsuoka, 2008; 

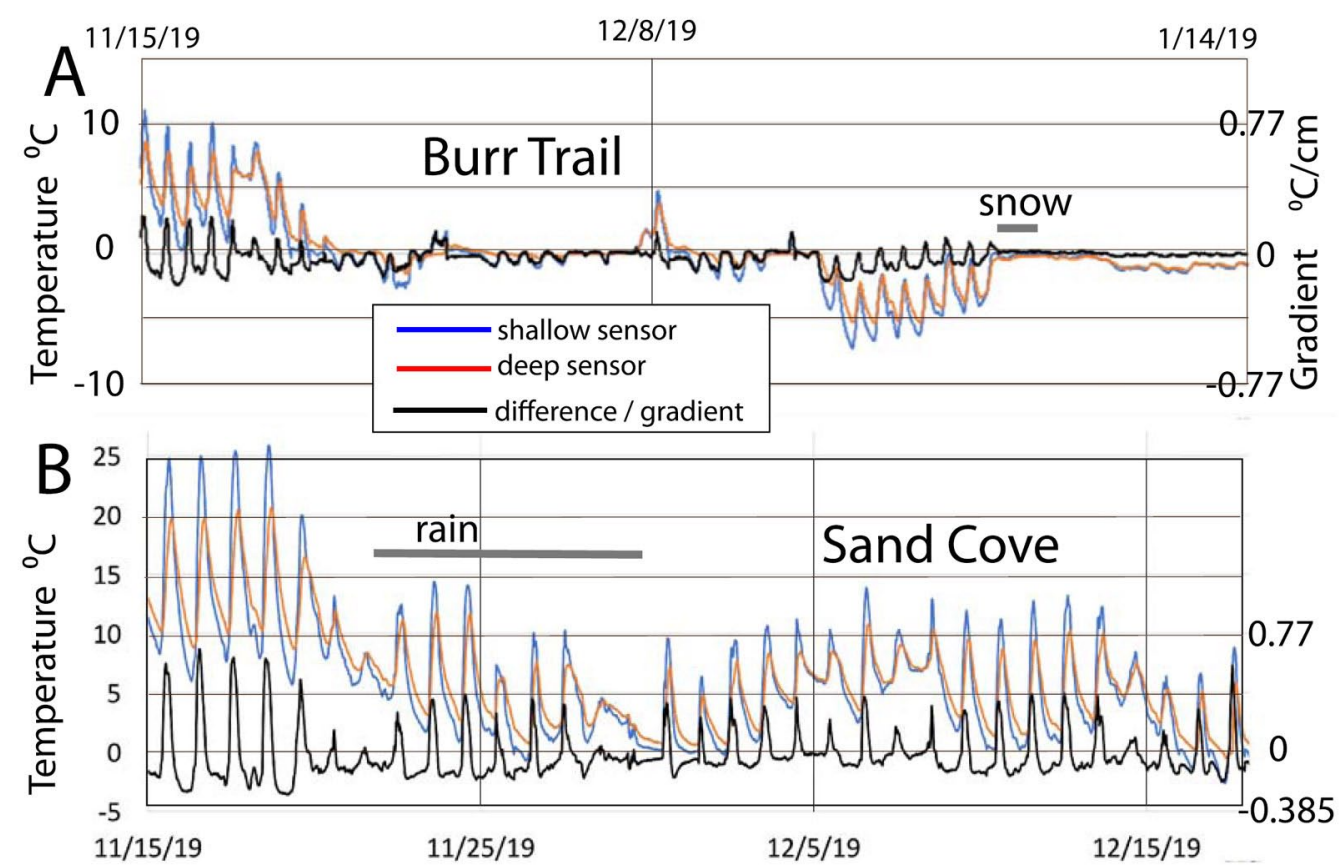

Figure 12. Fall and Winter thermal data from the Burr Trail site (highest elevation and coldest winters) and the Sand Cove site (lowest elevation and warmest winters; Figures 1 and 3). At Burr Trail (A), a $10 \mathrm{~cm}$ snowfall on December 24 reduced rock temperature fluctuations to less than $1.3^{\circ} \mathrm{C}$ for five days. Maintenance of the rock temperature near $0^{\circ} \mathrm{C}$ was likely due to the zero-curtain - an effect that develops in water-rich soils and sandto silt-sized sediments due to the loss and absorption of latent heat and to vapor transport during freeze-thaw cycles (Outcalt et al., 1990; Matsuoka, 2008; Draebing et al., 2017). At Sand Cove (B), prolonged rains (November 20-30 $=6.3 \mathrm{~cm}$ ) and cooler temperatures dramatically reduced temperature fluctuations and differences between sensors, but, with clearing, larger fluctuations returned in early December. After December 17, thermal gradients were weak because temperature differences between sensors at Sand Cove did not increase above $-3.6^{\circ} \mathrm{C}$ through the end of logging on March 10, 2020.

Draebing et al., 2017). At Sand Cove on November 19, 2019 at 4:00 a.m. the temperature difference between sensors was $3.6^{\circ} \mathrm{C}$. No greater differences were recorded before recording ended on March 10, 2020. From November 1, 2019 through to March 10, 2020, no snow was recorded at the St George weather station, but $12.5 \mathrm{~cm}$ of rain fell. We conclude that although contractile gradients in winter are insufficient to open polygonal fractures, freeze-thaw processes that accompany snowfalls (Figure 12) are likely to contribute to granular disintegration. 
The abundance of broad hexagonal fracture patterns developed on outcropping sandstones is, at first, puzzling. Whereas orthogonal fracture patterns form on many surfaces exposed to cooling or drying (Bohn et al., 2005), hexagonal patterns ( $Y>>$ T junctions) do not form on the surfaces of cooling lava or on desiccating starch, but evolve within those materials, well below the surface (Ryan and Sammis, 1981; De Graff and Aydin, 1987; Jagla, 2002; Bohn et al., 2005; Goehring, 2008, 2013; Goehring et al., 2010). Cracks in basalt form three-dimensional prisms that are hexagonal in cross-section, not hexagonal patterns restricted to a single, two-dimensional surface (Weaire and O'Carroll, 1983; Aydin and DeGraff, 1988). As a steep thermal gradient descends from the top of the lava flow or ascends from its base, the hexagonal form of the prisms emerges from an initial orthogonal pattern via iterative cracking events. Vertices slowly migrate laterally, evolving from T's to curved T's to pseudo Y's and, finally to Y's (Figure 13; Aydin and DeGraff, 1988; Goehring, 2013). Diurnal thermal cycles and rain events, however, generate a contractile temperature gradient sufficient to fracture sandstone that is (unlike the gradient in the lava flow) tied to an exposed land surface and therefore restricted to very shallow depths. These gradients cannot move vertically through bedrock at a rate comparable to those that follow solidifying lava, but they are nonetheless capable of driving iterative cracking (Figure 14).

Goehring et al. (2010) showed that hexagonal fracture patterns can be produced in a single, thin mud layer if that mud is repeatedly wetted and dried. They demonstrated that an original orthogonal, twodimensional pattern in soft material can be altered into a hexagonal, two-dimensional pattern via processes analogous to those operating in cooling lava. The Navajo sandstone is, however, a brittle solid and has been so for many million years. Development of a two-dimensional, hexagonal pattern on outcropping bedrock requires another process: granular disintegration.

At southern Utah sites where mass wasting events are rare, sandstone surfaces are steadily eroded by granular disintegration (Schumm and Chorley, 1966; Howard and Kochel, 1988). Our model for the origin of hexagonal patterns in the Navajo starts with an orthogonal pattern of fractures generated by contractile thermal stresses. As granular disintegration leads to removal of surficial material, the unfractured 


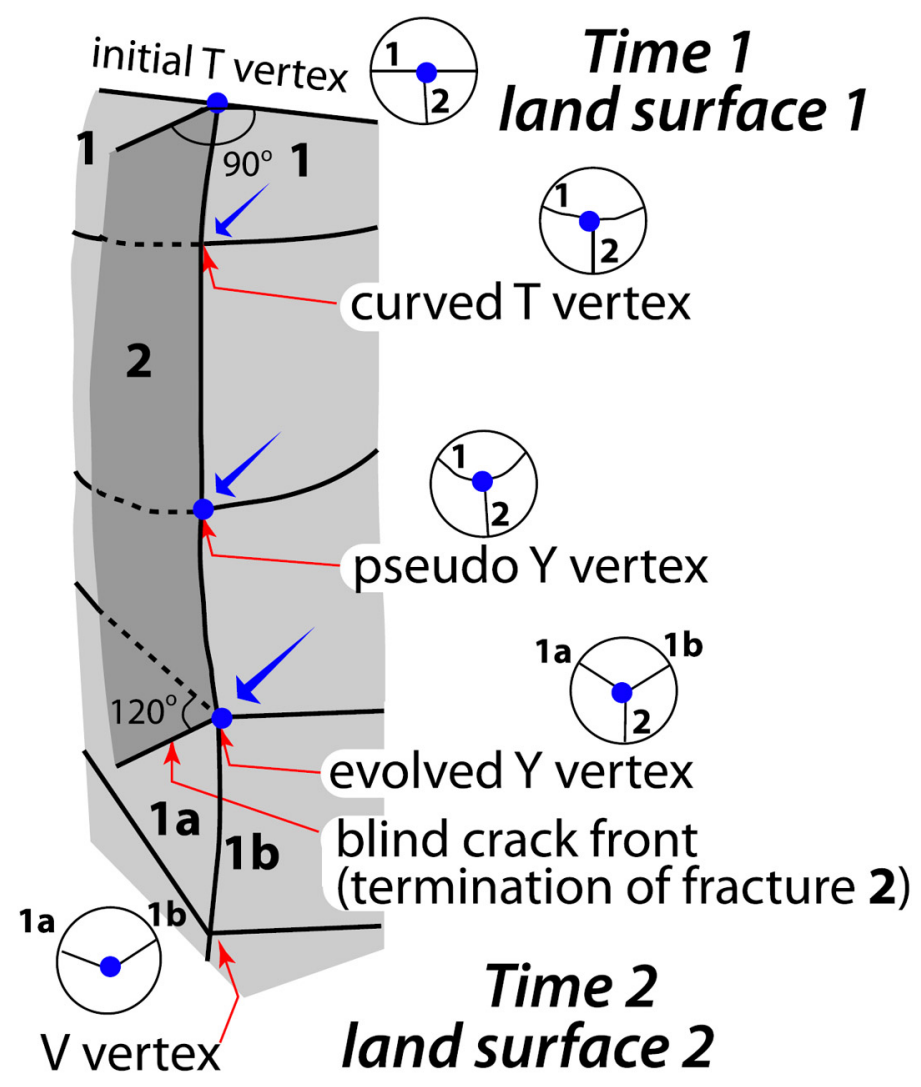

Figure 13. Model for the temporal evolution from a T-vertex to a Vvertex. Fracture 2 was the part of the initial T-vertex that arrived last, meeting an older fracture (fracture 1) at a right angle. Through iterative fracture extension, the vertex (small blue sphere) drifted toward the viewer (blue arrows), pulling fracture 1 behind it, changing the angle between fractures from $90^{\circ} / 90^{\circ} / 180^{\circ}$ to $120^{\circ}$ all around. Eventually, this fracture failed to stay ahead of the descending erosion surface, leaving $1 a$ and $1 \mathrm{~b}$ to form a V-vertex $\left(120^{\circ} / 240^{\circ}\right)$. Modified from Aydin and DeGraff (Aydin and DeGraff, 1988, figure 7) and Goehring (2013), who used this diagram (without the erosion phase) to illustrate the evolution of hexagonal columns in lava and starch.

rock beneath these fractures gradually enters the zone of strong thermal stresses (Figure 14). These episodic stresses cause existing fractures to iteratively extend into the underlying bedrock, creating new patterns while the pre-existing pattern is erased by erosion. This interpretation is supported by local abundances of ' $Y$ ', ' $V$ ' and ' $U$ ' vertices mixed amongst ' $T$ ' and ' $X$ ' vertices of dominantly rectilinear, sometimes ladder-like patterns (Bohn et al., 2005, figure 4b) at Yellow Knolls, Sand Cove, and Buckskin Gulch (Figures 8, 15, 16). 


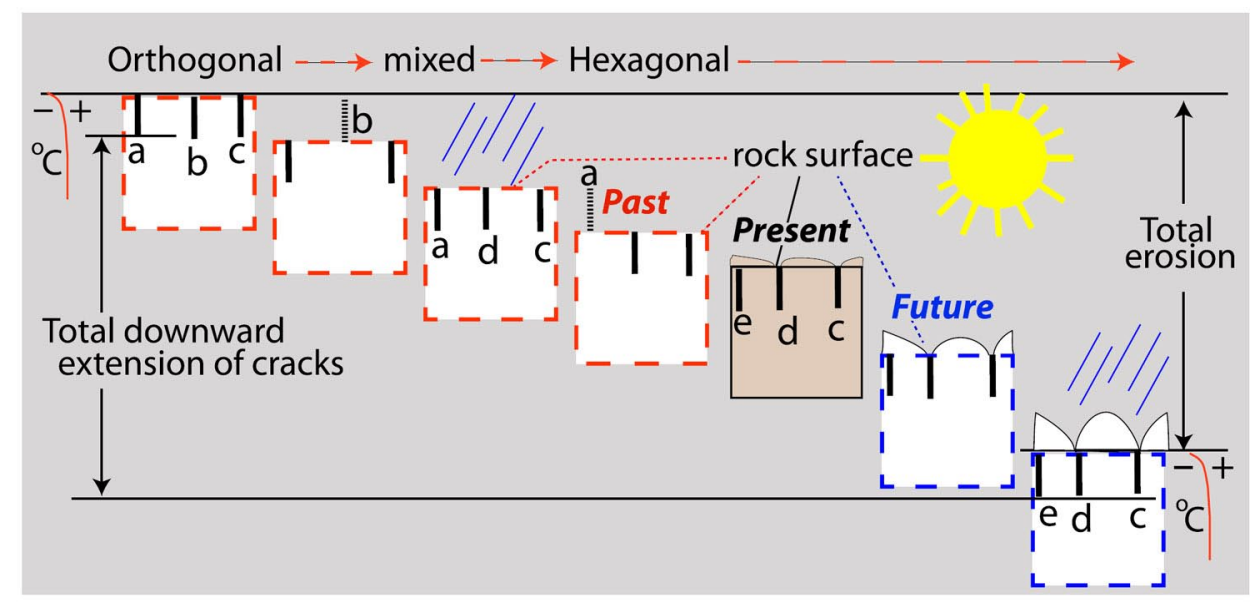

Figure 14. Diagrammatic, cross-sectional view of fractures in a shallow network that is perpetuated through time as erosion lowers the surface of exposed rock. As solar-driven diurnal temperature cycles and rainfall remain constant, thermal stresses drive the fractures downward and laterally, extending them into underlying rock at about the same rate that erosion proceeds. One individual fracture (fracture c) persists; fractures $a$ and $b$ fail to maintain sufficient depth to avoid the descending erosion surface, but are replaced by fractures $d$ and e. Fractures e, $d$, and c are maintained due to the increased convexity that develops on the land surface (Figure 7), causing runoff water (directed toward the fractures) to weaken the rock near the propagating fracture tips.

Further support comes from evidence that elongate, zig-zagging fractures can be simply explained by distortion of long, straight fractures by lateral migration of vertices away from the long-fracture axis, along the trend of cross joints (Figures 8, 15, 16A).

Fracture patterns in both cooling lava and desiccating starch continue to evolve even after a near-perfect hexagonal pattern has formed (Goehring, 2008). Following the topological work of Weaire and Rivier (2009), and working with desiccating starch, Goehring (2008, figure 2.33a), showed that if (starting with a 'perfect' hexagonal pattern) vertices drift laterally, the length of a single bounding fracture within a cluster of four adjacent hexagons of equal size can shrink to zero, allowing one hexagon to penetrate another. This results in a gain of two pentagonal and two heptagonal prisms (all of equal size), and the loss of four hexagons. This continuing evolutionary process helps to explain a similarity between a Navajo fracture pattern and the network displayed by the Giant's Causeway lava flow (Figure 6C): 

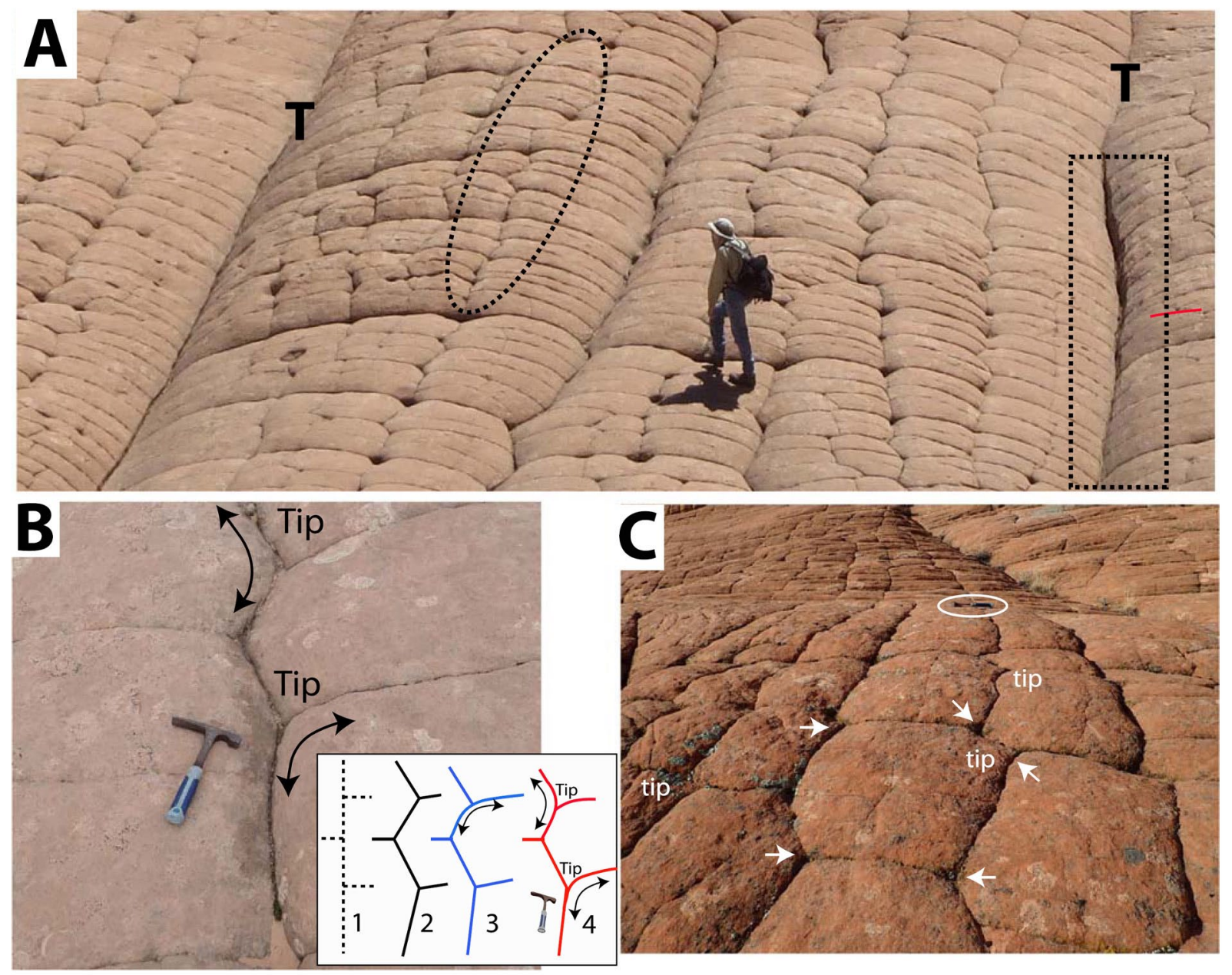

Figure 15. Intermediates in the transition from an orthogonal to a hexagonal fracture pattern. In all three examples, original orthogonal patterns were rectilinear, with fractures parallel to sides of photographs. (A) Extensive, ladder-like, orthogonal pattern in an early stage of evolution, cut by two tectonic joints $(\mathrm{T})$. Rectangle encloses T-vertices that did not migrate because the ancient, through-going tectonic joint did not iteratively fracture near the land surface; within the oval, vertices were not influenced by a tectonic joint. These migrated laterally, generating numerous Y-vertices and stretched hexagons. Rock surface slopes toward viewer and is underlain by sheeting joints (Buckskin Gulch; see Loope and Burberry, 2018, figures 10-12). (B) Close-up of curved surficial fractures and evolved vertices (Buckskin Gulch). On weathered outcrops, the acute angles near Y-vertices of rock 'tips' sculpted by one or more curving fractures are distinctive (inset; see also Figure 16B). (C) White arrows are aligned with nearby fractures and point in the direction of migration of a vertex (see Figure 13; Sand Cove). 

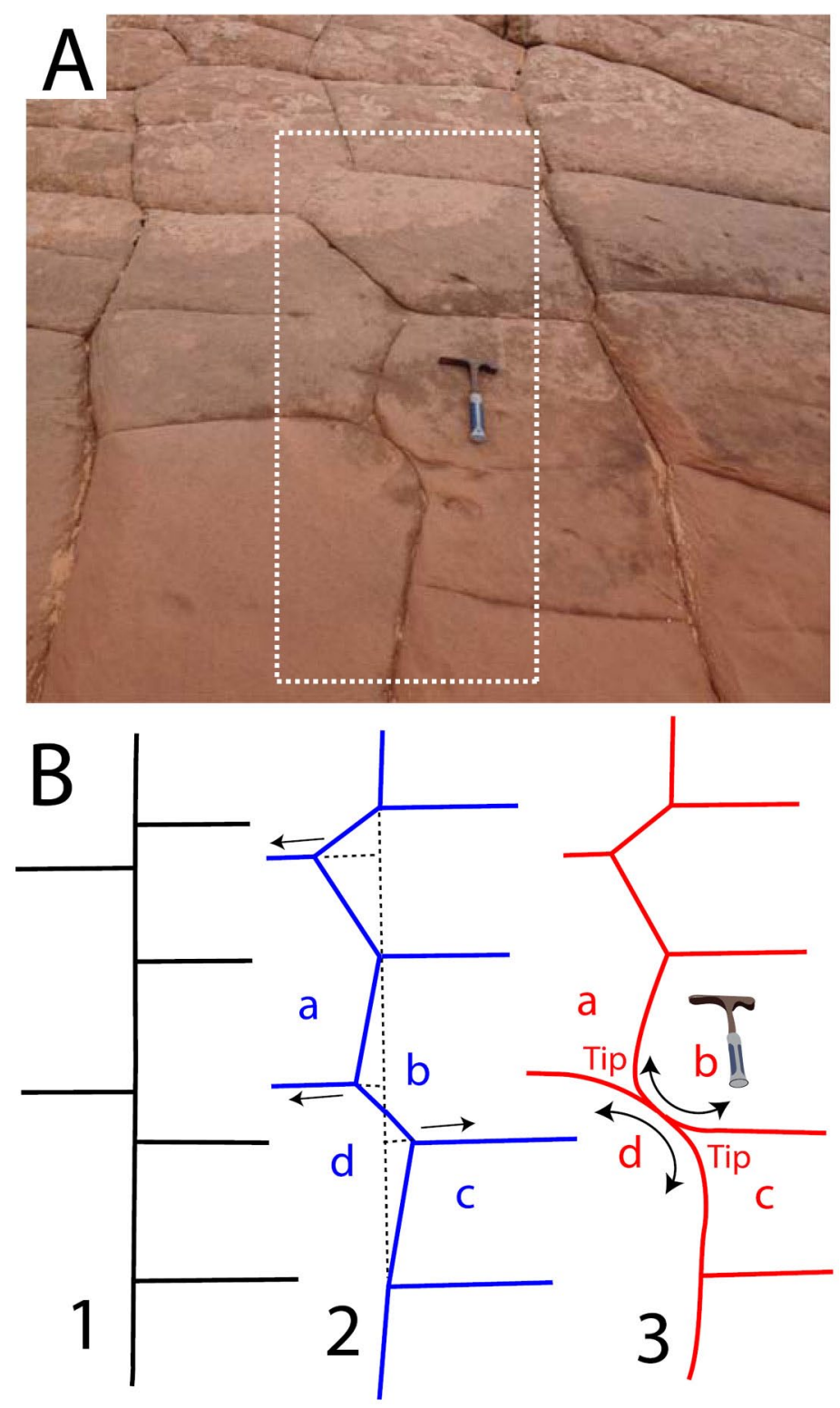

Figure 16. Interpretation of the evolution of a fracture pattern. (A) Fracture pattern at Buckskin Gulch. (B) Long fracture in sketch 1 is oldest. It was later met at right angles by six cross joints, forming T-vertices. Iterative cracking events caused this ancestral pattern to be altered by two processes: migration of vertices (sketch 2), and rounding of the vertices (sketch 3). T-vertices changed to Y-vertices when vertices migrated along the length of the cross fractures, away from the position of the ancestral fracture. Rounding of the vertices resulted from fracturing events that repeatedly drove these cracks not only downward, but also in different lateral directions (see Goehring, 2013, figure 3). 
the percentages of five-sided and of seven-sided polygons are nearly equal, and hexagons make up more than double that percentage (Figure $6 A, B$; Budkewitsch and Robin, 1994, figure 14). This similarity is consistent with our proposal that the Navajo's fracture pattern evolved (like those in lava flows) via lateral drift of vertices.

Composite polygons (Figures 6, 8) appear to be unique to sandstone - they do not develop in cooling basalt flows or desiccating starch. Evidence of erosion should be expected in shallow, surficial fracture systems, and the abundance and distribution of composite polygons in the hexagonal pattern mapped at Yellow Knolls (Figure 6A) is consistent with that expectation. The continuity of ' $\mathrm{V}$ ' vertices along the perimeters of composite polygons (Figure $8 \mathrm{~B}$ ) suggests that erosional processes selectively eliminate (entire) individual fractures from the larger pattern. If surficial fractures independently propagate downward, it would be unlikely for all to propagate at the same rate; this would make some less vulnerable to erasure than others. If, for example, cracks propagate downward primarily during rainstorms, cracks receiving more runoff would propagate faster than neighboring cracks, and would be preferentially preserved (Figures 7, 13, 14).

\section{Conclusions}

1. During summers in southern Utah, sandstone with low tensile strength and abundant shallow sheeting fractures and surficial polygons is subjected to diurnal fluctuations in rock temperature of up to $25^{\circ} \mathrm{C}$.

2. Shallow sheeting joints in the Navajo sandstone are likely triggered by rock expansion on hot summer days.

3. Relatively minor rainfall events on summer afternoons generate contractile temperature gradients and cooling rates that are twice the magnitude of those produced by dry overnight cooling. Such events (as well as major rainstorms) are the most likely source of the contractile stress that opens and drives polygonal fractures.

4. Fracture patterns that are intermediate between orthogonal and hexagonal indicate that, as in basalts and desiccating starch, fracture vertices in sandstone migrate laterally causing orthogonal patterns to evolve to hexagonal patterns of similar scale. 
5. By slowly lowering the rock surface, granular disintegration allows surficial fracture patterns to remain in the thin zone where repeated, downward fracture extensions are possible. This iterative cracking generates extensive hexagonal patterns on geomorphologically stable sandstone surfaces. Where mass wasting is active, orthogonal patterns may not have sufficient time to evolve.

Acknowledgements-The authors thank Colby Ford, Ranjan Fernando, and Kevin Loope for their help with fieldwork, Daren Blythe for his interest and general assistance, Alan Titus (Bureau of Land Management; Grand Staircase National Monument) for his cooperation and advice, and Owen Severance for his keen eye. Stuart Lane and two anonymous reviewers provided numerous insightful suggestions. This research was supported by funds from the Schultz Chair in Stratigraphy, University of Nebraska Foundation.

Conflict of Interest - There are no conflicts of interest to declare.

Data Statement - The data sets used and/or analyzed during the current study are available from the corresponding author on reasonable request.

\section{References}

Abbey E, Hyde P. 1971. Slickrock: The Canyon Country of Southeast Utah. Sierra Club: San Francisco, CA; 143.

Andersen JL, Egholm DL, Knudsen MF, Jansen JD, Nielsen SB. 2015. The periglacial engine of mountain erosion-1. Earth Surface Dynamics 3: 447-462.

Anderson RS. 1998. Near-surface thermal profiles in alpine bedrock: Implications for the frost weathering of rock. Arctic and Alpine Research 30: 362-372.

Aydin A, DeGraff JM. 1988. Evolution of polygonal fracture patterns in lava flows. Science 239(4839): 471-476.

Aydin A, Johnson AM. 1983. Analysis of faulting in porous sandstones. Journal of Structural Geology 5(1): 19-31. Beard CN. 1959. Quantitative study of columnar basalt. Geological Society of America Bulletin 70: 379-382.

Bohn S, Platkiewicz J, Andreotti B, Adda-Bedia M, Couder Y. 2005. Hierarchical crack pattern as formed by successive domain divisions. II. From disordered to deterministic behavior. Physical Review E 71: 1-7, 046215 s2005d.

Bradley WC. 1963. Large-scale exfoliation in massive sandstones of the Colorado Plateau. Geological Society of America Bulletin 74: 519-528. https://doi. org/10.1130/0016-7606(1963)74[519:LEIMSO] 2.0.CO;2. 
Branagan DF. 1983. Tesselated pavements. In Aspects of Australian Sandstone Landscapes. Australian and New Zealand Geomorphology Group: Wollongong, NSW; 11-20.

Bryant G, Monegato G, Miall A. 2013. Example of liquefaction-induced interdune sedimentation from the Jurassic Navajo Sandstone, USA. Sedimentary Geology 297: 50-62. https://doi.org/10.1016/j. sedgeo.2013.09.001.

Budkewitsch P, Robin PY. 1994. Modelling the evolution of columnar joints. Journal of Volcanology and Geothermal Research 59: 219-239.

Chan MA, Yonkee WA, Netoff DI, Seiler WM, Ford RL. 2008. Polygonal cracks in bedrock on Earth and Mars: Implications for weathering. Icarus 194: 65-71. https://doi.org/10.1016/j.icarus.2007.09.026.

Collins BD, Stock GM. 2016. Rockfall triggering by cyclic thermal stressing of exfoliation fractures. Nature Geoscience 9: 395-400.

Collins BD, Stock GM, Eppes M, Lewis SW, Corbett SC, Smith JB. 2018. Thermal influences on spontaneous rock dome exfoliation. Nature Communications 9: 1-12, 762. https://doi.org/10.1038/s41467-017-02728-1.

Crampton CG. 1973. Standing Up Country: The Canyon Lands of Utah and Arizona. University of Utah, Alfred A. Knopf: New York; 191.

De Graff JM, Aydin A. 1987. Surface morphology of columnar joints and its significance to mechanics and direction of joint growth. Geological Society of America Bulletin 99: 605-617.

Draebing D, Krautblatter M, Hoffmann T. 2017. Thermo-cryogenic controls of fracture kinematics in permafrost rockwalls. Geophysical Research Letters 44: 3535-3544.

Eppes M-C, Keanini R. 2017. Mechanical weathering and rock erosion by climatedependent subcritical cracking. Reviews of Geophysics 55: 470-508.

Eppes M-C, Magi B, Hallet B, Delmelle E, Mackenzie-Helnwein P, Warren K, Swami S. 2016. Deciphering the role of solar-induced thermal stresses in rock weathering. Geological Society of America Bulletin 128: 1315-1338. https://doi. org/10.1130/B31422.1.

Goehring L. 2008. On the scaling and order of columnar joints. University of Toronto, PhD Dissertation, $160 \mathrm{pp}$.

Goehring L. 2013. Evolving fracture patterns: columnar joints, mud cracks, and polygonal terrain. Philosophical Transactions of the Royal Academy A 371: 1-18, 20120353.

Goehring L, Conroy R, Akhter A, Clegg WJ, Routh AF. 2010. Evolution of mudcrack patterns during repeated drying cycles. Soft Matter 6: 3562-3567.

Guha Roy D, Singh TN, Kodikara J, Das R. 2017. Effect of water saturation on the fracture and mechanical properties of sedimentary rocks. Rock Mechanics and Rock Engineering 50: 2585-2600.

Hadizadeh J, Law RD. 1991. Water-weakening of sandstone and quartzite deformed at various stress and strain rates. International Journal of Rock Mechanics and Mineral Science 28: 431-439. 
Hamilton WL, Steebler J, Jackson VL. 1984. The Sculpturing of Zion. Zion Natural History Association: Springdale, UT; 132.

Heap MJ, Baud P, Meridith PG. 2009. Influence of temperature in brittle creep in sandstones. Geophysical Research Letters 36: 1-6, L19305. https://doi. org/10.1029/2009GL039373.

Holzhausen GR. 1989. Origin of sheet structure, 1. Morphology and boundary conditions. Engineering Geology 27: 225-278. https:// doi. org/10.1016/0013-7952(89)90035-5.

Howard AD, Kochel RC. 1988. Introduction to cuesta landforms and sapping processes on the Colorado Plateau. In Sapping Features of the Colorado Plateau, A Comparative Planetary Geology Field Guide, Howard AD, Kochel RC, Holt HE (eds). NASA, Scientific and Technical Information Division: Washington, DC; 6-56.

Jagla EA. 2002. Stable propagation of an ordered array of cracks during directional drying. Physical Review E 65: 1-7, 046147.

Jagla EA, Rojo AG. 2002. Sequential fragmentation: The origin of columnar quasihexagonal patterns. Physical Review E 65: 1-6, 026203.

Johnston CS. 1927. Polygonal weathering in igneous and sedimentary rocks. American Journal of Science 77: 440-444.

Kocurek G, Dott RH, Jr. 1983. Jurassic paleogeography and paleoclimate of the central and southern Rocky Mountains region. In Mesozoic Paleogeography of the West-Central United States, Reynolds MW, Dolly ED (eds), Vol. 2, Rocky Mountain Paleogeography Symposium. Rocky Mountain Section, Society of Economic Paleontologists and Mineralogists: Denver, CO; 101-116.

Lachenbruch AH. 1962. Mechanics of Thermal Contraction Cracks and Ice-Wedge Polygons in Permafrost: Geological Society of America Special Paper 70, 69 pp.

Loope DB, Burberry CM. 2018. Sheeting joints and polygonal patterns in the Navajo Sandstone, southern Utah: Control by rock fabric, tectonic joints, buckling, and gullying. Geosphere 14(4): 1818-1836. https://doi.org/10.1130/ GES01614.1.

Loope DB, Rowe CM. 2003. Long-lived pluvial episodes during deposition of the Navajo Sandstone. Journal of Geology 111: 223-232. https://doi. org/10.1086/345843.

Martel SJ. 2006. Effect of topographic curvature on near-surface stresses and application to sheeting joints. Geophysical Research Letters 33: 1-5, L01308. https://doi.org/10.1029/2005GL024710.

Martel SJ. 2011. Mechanics of curved surfaces, with application to surfaceparallel cracks. Geophysical Research Letters 38: 1-6, L20303. https://doi. org/10.1029/2011GL049354.

Martel SJ. 2017. Progress in understanding sheeting joints over the past two centuries. Journal of Structural Geology 94: 68-86. https://doi. org/10.1016/j. jsg.2016.11.003.

Matsuoka N. 2008. Frost weathering and rockwall erosion in the eastern Swiss Alps: Long-term (1994-2006) observations. Geomorphology 99: 353-368. 
Michalske TA, Freiman SW. 1982. A molecular interpretation of stress corrosion in silica. Nature 295: 511-512.

Netoff DI. 1971. Polygonal jointing in sandstone near Boulder, Colorado. Mountain Geologist 8: 17-24.

Outcalt SI, Nelson FE, Hinkel KM. 1990. The zero-curtain effect: Heat and mass transfer across an isothermal region in freezing soil. Water Resources Research 26(7): 1509-1516.

Parry WT, Forster CB, Evans JP, Beitler-Bowen B, Chan MA. 2007. Geochemistry of $\mathrm{CO}_{2}$ sequestration in the Jurassic Navajo Sandstone, Colorado Plateau, Utah. Environmental Geosciences 14(2): 91-109.

Riley P, Murray AB, Tikoff B. 2012. Geometric scale invariance, genesis, and selforganization of polygonal fracture networks in granitic rocks. Journal of Structural Geology 42: 34-48. https://doi.org/10.1016/j.jsg.2012.07.001.

Robinson ES. 1970. Mechanical disintegration of the Navajo Sandstone in Zion Canyon, Utah. Geological Society of America Bulletin 81: 2799-2806. https://doi. org/10.1130/0016-7606(1970)81[2799: MDOTNS]2.0.CO;2.

Robinson DA, Williams RBG. 1992. Sandstone weathering in the High Atlas, Morocco. Zeitschrift für Geomorphologie 36(4): 413-429.

Ryan MP, Sammis CG. 1981. The glass transition in basalt. Journal of Geophysical Research 86(B10): 9519-9535.

Schumm SA, Chorley RJ. 1966. Talus weathering and scarp recession on the Colorado Plateau. Zeitschrift für Geomorphologie 10: 11-36.

Stock GM, Martel SJ, Collins BD, Harp EL. 2012. Progressive failure of sheeted rock slopes: The 2009-2010 Rhombus Wall rock falls in Yosemite Valley, California, USA. Earth Surface Processes and Landforms 37: 546-561. https://doi. org/10.1002/esp.3192.

Thomas M, Clarke JDA, Pain CF. 2005. Weathering, erosion and landscape processes on Mars identified from recent rover imagery, and possible Earth analogues. Australian Journal of Earth Sciences 52(3): 365-378.

Velazquez VF, Fonseca Giannini PC, Mini CR, Martins Sallun AE, Hachiro J, de Barros Gomes C. 2008. Columnar joints in the Patiño formation sandstones, eastern Paraguay: A dynamic interaction between dyke intrusion, quartz dissolution and cooling-induced fractures. Episodes 31(3): 302-308.

Weaire D, Hutzer S. 1999. The Physics of Foams. Oxford University Press: Oxford; 243.

Weaire D, O'Carroll C. 1983. A new model for the Giant's Causeway. Nature 302: 240-241.

Weaire D, Rivier N. 2009. Soap, cells and statistics - random patterns in two dimensions. Contemporary Physics 50(1): 199-239. https:// doi. org/10.1080/00107510902734680.

Williams R, Robinson D. 1989. Origin and distribution of polygonal cracking of rock surfaces. Geografiska Annaler. Series A, Physical Geography 71: 145-159. https://doi.org/10.1080/04353676.1989.11880283. 
Wong IG, Humphrey JR. 1989. Contemporary seismicity, faulting, and the state of stress in the Colorado Plateau. Geological Society of America Bulletin 101: 1127-1146.

Wong LNY, Maruvanchery V, Liu G. 2016. Water effects on rock strength and stiffness degradation. Acta Geotechnica 11: 713-737. https://doi.org/10.1007/ s11440-015-0407-7.

Young RW, Wray RA, Young ARM. 2009. Sandstone Landforms. Cambridge University Press: Cambridge; 304.

Zhou Z, Cai X, Ma D, Cao W, Chen L, Zhou J. 2018. Effects of water content on fracture and mechanical behavior of sandstone with a low clay mineral content. Engineering Fracture Mechanics 193: 47-65.

Zhou Z, Cai X, Ma D, Du X, Chen L, Wang H, Zang H. 2019. Water saturation effects on dynamic fracture behavior of sandstone. International Journal of Rock Mechanics and Mining Sciences 114: 46-61.

Zoback ML, Zoback MD. 1989. Tectonic stress field of the continental United States. In Geophysical Framework of the Continental United States, Pakiser LC, Mooney WD (eds), Vol. 172. Geological Society of America Memoir: Menlo Park, CA; 523-540 10.1130/MEM172p523. 